\title{
Making sense of farmers' demand for seed of root, tuber and banana crops: a systematic review of methods
}

\author{
Thomas Pircher ${ }^{1,2}$ (D) Conny J. M. Almekinders ${ }^{2,3}$ (I) \\ Received: 17 September 2020 / Accepted: 4 March 2021 / Published online: 29 April 2021 \\ (C) The Author(s) 2021
}

\begin{abstract}
A demand-driven approach is becoming increasingly central in the efforts to improve agricultural research and development. However, the question of how exactly demand is studied usually remains unstated and is rarely discussed. We therefore carried out a systematic review in order to better understand how farmers' demand for seed in root, tuber and banana seed systems is studied. The review is based on data from a consultation with an expert panel and a structured literature search in the SCOPUS database. Screening the gathered articles resulted in 46 studies on a global scale, fitting the scope of our investigation. Through qualitative analysis and categorization of these studies, we developed a classification scheme according to the types of approaches applied in the retained studies. One group of studies explicitly articulates farmers' preferences and choices through surveys or engagements in trials, auctions, choice experiments and interviews. Other studies implicitly articulate farmers' demand by characterising their current use of varieties and seed. We discuss opportunities and limitations in the use of each type of study and we reflect on the body of available literature as a whole. Our conclusion is that a framework is necessary that purposefully combines the existing different methods and that it is necessary to involve stakeholders in a process where demand is articulated. Together, these two steps would characterise existing demands in a more effective and precise way, thus providing better guidance to decision-makers in their reactions pertaining to seed systems.
\end{abstract}

Keywords Farmers' demand $\cdot$ Demand articulation $\cdot$ Research methods $\cdot$ RTB seed systems

\section{Introduction}

\subsection{Understanding farmers' demand for the seed of RTB crops}

Seeds ${ }^{1}$ of adapted crop varieties with more productive and nutritious traits are a fundamental requirement to increase food

\footnotetext{
${ }^{1}$ In this article we use the term seed in its true botanical meaning, as well as in reference to planting material of vegetatively propagated crops.
}

Thomas Pircher

thomas.pircher@uni-hohenheim.de

1 Research Center for Global Food Security and Ecosystems, University of Hohenheim, Wollgrasweg 43, 70599 Stuttgart, Germany

2 CGIAR Research Program on Roots, Tubers and Bananas (RTB), Lima, Peru

3 Knowledge, Technology and Innovation group, Social Sciences, Wageningen University, Hollandseweg 1, 6706, KN, Wageningen, The Netherlands security and strengthen the resilience of smallholder farmers (McGuire and Sperling 2011; Savary et al. 2020). Wellfunctioning seed systems are essential to ensure that highquality seed of such varieties is available and accessible to farmers (Almekinders et al. 1994; Louwaars and De Boef 2012; McGuire and Sperling 2016). A central aspect of seed system improvement is to become more responsive and proactive to the needs of different user-groups for better seeds and to promote demand-driven innovation in breeding programmes and seed systems. Demand-driven research and development approaches have become central since Farmer First thinking, inspired by people such as Robert Chambers et al. (1989), became mainstream. The need for truly demand-driven approaches is prominently and frequently referred to in the current discussions about how to transform the agricultural research and development approach within the CGIAR (CGIAR 2020). However, how exactly farmers' technology demand is defined and, consequently, how it is studied, remains usually unstated and is rarely discussed. This study reports the results of a systematic literature review that explores and analyses scientific publications addressing farmers' demand for seed. 
Farmers' demand for seed is an expression that is readily used in seed system studies without specific definition or discussion of the concept. In plant breeding, farmers' demand has been addressed through participatory approaches (e.g. Almekinders and Elings 2001; Ceccarelli and Grando 2007, 2019; Sperling et al. 2001; Weltzien et al. 2003), and more specifically by John Witcombe (Witcombe et al. 2005; Witcombe and Yadavendra 2014) who argued for client-driven plant breeding. Some other examples of studying demand for seed include estimating the required volumes or quantities of seed to prevent over or under stocking by suppliers (e.g. Spielman and Mekonnen 2013), identifying preferred variety traits, and the prices farmers are willing to pay for seed. The last type of assessment, willingness to pay (WTP) studies, includes a variety of approaches, reviewed by Breidert et al. (2006). Some are using WTP as a proxy for willingness to adopt (Olum et al. 2019). In this review, we are interested in discovering how demand for the seed of root, tuber and banana (RTB) crops has been studied.

Many crops are reproduced vegetatively, through roots, tubers, stems, suckers and vines. These plant parts can be multiplied easily by farmers themselves while remaining genetically true to type. The bulky and perishable nature of RTB planting material is a major reason why a majority of farmers multiply these seeds themselves or share, swap or trade them with neighbours, friends and relatives rather than buying them and/or transporting over longer distances (McGuire and Sperling 2016). A disadvantage of continued clonal reproduction is that viruses and other pathogens can easily accumulate in vegetative material over time, resulting in yield losses (Okonya et al. 2019; Thomas-Sharma et al. 2016, 2017). These vegetatively propagated crops play an important role in providing food and income for more than 300 million people worldwide (RTB 2021). Despite their importance, these seed systems have received comparatively little attention from research and development (Almekinders et al. 2019b). They are mostly informal, and there is little understanding of farmers' demand for such seed from formal sources (Almekinders et al. 2019b).

\subsection{The concept of demand and its articulation}

The core of this literature review is the concept of demand, the definition of which varies across different fields of science. Interdisciplinary dialogues among economists and sociologists contributed to bringing new perspectives to study the role of demand in innovation processes (McMeekin et al. 2002). In economic terms, demand is defined as the quantity of a good that consumers are willing and able to purchase at various prices during a given period of time (O'Sullivan and Sheffrin 2003) and this can be plotted on a demand curve. A demand equation is a mathematical expression that relates the quantity of a demanded good to a set of factors that affect both the willingness and ability of a consumer to purchase it. These factors also include characteristics that are not directly related to the price of the product. In the case of seed, aspects such as seed quality, taste preferences, market for produce, and the socio-economic attributes of the consumer affect farmers' demand. For example, when farmers' cash income increases, their demand for seed may rise.

From a sociological perspective, demand, on the other hand, is studied in relation to innovation and stems from the concept of user needs, which is meant to address societal and political needs with innovation. User needs refer to the quality or properties of a product or service, whereas demand in an economic sense refers to the quantity (Peine and Herrmann 2012). In case needs are not met by already existing products and services, their nature is latent, vague and potentially unlimited and therefore difficult to capture (Boon and Edler 2018). Earlier efforts in understanding these less well-defined needs have actually led to successful technological innovation projects (Teubal and Twiss 1979; von Hippel 1976, 1977). However, Mowery and Rosenberg (1979) criticised the concept of user needs as elusive and incapable to drive research if not clearly separated from demand. In response to this critique, the need-pull model for technological innovation was subsequently labelled as demand-pull and later-on was integrated into multidimensional models. The term need subsequently disappeared from the literature on user innovation and was replaced by the term demand, which is now used in economic theory and models (Godin and Lane 2013).

Despite the disappearance of the term need in innovation studies and the emphasis on the use of demand in its economic sense, the concept demand continues to include less-defined needs or visions of a technology or service. Earlier studies conceptualized and described this type of demand: Boon (2008, p. 46) defines demand as "explicit, univocal statements of actors on how they regard (the future concerning) a technology and which issues regarding this technology should be included or addressed by other stakeholders". This form of demand is also referred to as substantive demand or substantive needs (Boon 2008; Klerkx et al. 2006; Leeuwis and van den Ban 2004). Sumberg and Reece (2004) coined the term incipient demand for agricultural innovations that are latent demands for a not-yet-existing product that is expected to exist in the future, which can be treated similarly to substantive demand. Bentley et al. (2007) studied farmers' implicit demands for farm technology that reflect "problems that the people themselves do not recognise (they will not demand control of potato viruses if they do not know that viruses exist), or for techniques which they have not imagined (e.g. they did not demand metal ploughs until they saw them)". All these conceptualizations refer to a latent form of demand that is not clearly defined and therefore difficult to articulate.

Alongside different forms of demand for seed, we recognise different aspects of demand. Tripp (2000) presented different types of demand for seed of grain and legume crops in subSaharan Africa on the basis of motivations of farmers to acquire seed. Based on that concept and recent literature of RTB seed 
systems (Almekinders et al. 2019b), we distinguish the following aspects of demand that are relevant for seed of RTB crops: Varietal traits which are defined by the genetic code of seed that is expressed in multiple traits, such as yield, disease resistance, culinary preferences of consumers, and marketability for produce; the physical quality of seed which is influenced by transport and storage of vegetative propagation material as well as the process of multiplication, i.e. presence or absence of diseases (Thomas-Sharma et al. 2016, 2017); the quantity of seed which refers to the amounts of seed that farmers are requesting from the market or other sources; and, seed sourcing characteristics which are defined by seed transactions and trade relationships how farmers access seed. Following scholars of the innovation studies field (Boon 2008; Boon et al. 2011; Boon and Edler 2018; Kilelu et al. 2014; Klerkx et al. 2006; Klerkx and Leeuwis 2008), we use the concept demand articulation to refer to approaches or methods that researchers use to enable stakeholders to express their preferences or choices. To study substantive or implicit demands, the research methods need to discover and explore the as-of-yet unarticulated demands of farmers. This can be done in a process of a creative learning that includes discussions between different stakeholders, both insiders and outsiders (Bentley et al. 2007; Leeuwis and van den Ban 2004). In order to understand this demand articulation process better, we reviewed scientific studies that describe which methods researchers used to make different forms and aspects of farmers demand for RTB seed explicit.

\section{Materials and methods}

\subsection{Data collection}

We followed three lines of enquiry in this review to identify relevant studies: an exploratory literature search, a consultation with an expert panel and a structured literature search in the SCOPUS database (https://www.scopus.com). When defining the scope of this study, i.e. farmers' demand for seed, we conducted an exploratory search in bibliometric databases Google Scholar (https://scholar.google.com) and SCOPUS. To further define the scope of our database, we set up a structured expert consultation, inviting the 35 participants of the annual meetings of the CGIAR RTB CC2.1 Working Group in 2017 and 2018. The participants of these meetings have backgrounds in different scientific disciplines including economics, plant pathology, agronomy, and rural sociology.

We contacted the panel of experts via email (on 15/05/ 2018) and asked for literature references, either scientific articles or other types of study, based on the following criteria:

- studies on potato, sweet potato, cassava, yam and banana and other RTB crops;
- studies that combine RTB crops with one or more nonRTB crops;

- studies that consider farmers' preferences or motivations for using quality planting material (e.g. clean seed over degenerated seed), and;

- willingness to pay and choice game studies.

In our request, we excluded adoption studies and studies of participatory plant breeding and variety selection (PPB and PVS) that focus on farmers trait preferences as we were well aware of existing literature reporting on these types of studies. In addition, we asked the panel to provide links to colleagues who might be aware of studies within the defined scope. Six weeks later (25/06/2018), we sent a reminder email to all participants. In the next step, we contacted each person individually (up to two times) to follow-up on the identification of literature sources and links to colleagues. The inquiry resulted in 54 unique literature references and nine links to colleagues outside the selected expert panel. We contacted the referred experts and followed up with each one individually, but this did not lead to the identification of any new literature references.

After the first qualitative screening of Abstracts, Conclusions, and if necessary the Results sections of the 54 study reports, we selected 23 reports (15 unpublished project reports, working papers and dissertations, and 8 peer reviewed articles) for further review, based on the following criteria:

- the studies were based on empirical data;

- the studies had a focus on one or more RTB crops;

- farmer demand for planting material was a substantial component of the study, and;

- the methodology which was used to understand farmer demand was presented in the study.

In the next step, we conducted a structured literature search in the bibliometric database SCOPUS. Informed by keywords and concepts that were mentioned in the abstracts of the study reports from the panel of experts, we searched in SCOPUS for additional articles. The following search query was constructed based on the search terms in Table 1:

Table 1 Identified keywords and their translation into search terms for literature search in SCOPUS

\begin{tabular}{|c|c|}
\hline Keywords & Search terms \\
\hline Smallholder farmers & farmer $*$, smallholder* \\
\hline $\begin{array}{l}\text { Type of study to } \\
\text { understand demand }\end{array}$ & $\begin{array}{l}\text { acqui }{ }^{*}, \text { sourc }^{*} \text {, demand, 'willingness to pay', } \\
\text { willingness-to-pay, 'choice experiment', } \\
\text { 'contingent valuation', 'use' }\end{array}$ \\
\hline RTB crops & banana*, cassava*, *potato*, yam*, \\
\hline Planting material & $\begin{array}{l}\text { 'planting material', 'propagation material', } \\
\text { seed, stem*, plantlet*, sucker*, vine*, } \\
\text { variet }^{*}\end{array}$ \\
\hline
\end{tabular}


TITLE-ABS-KEY ( ( farmer* OR smallholder* ) AND ( acqui* OR sourc* OR demand OR "willingness to pay" OR willingness-to-pay OR "choice experiment" OR "contingent valuation" OR "use" ) AND ( banana* OR cassava* OR *potato* OR yam*) AND ( "planting material" OR "propagation material" OR seed OR stem* OR plantlet* OR sucker* OR vine* OR "variet*" ) ) AND ( LIMIT-TO ( DOCTYPE , "ar" ) ) AND ( LIMIT-TO ( LANGUAGE , "English" ))

Limited to the document type 'article' and English language, the query resulted in 444 articles (09/12/2019). We exported bibliographic information (including abstracts) from the search results in a CSV-file for screening the results according to the defined inclusion criteria listed earlier. Screening the abstracts and keywords of these articles for relevance, we arrived at 70 articles. We were able to download 68 full texts from SCOPUS, publishers' websites and Research Gate (two articles were not accessible on the journal websites thus not considered in the literature review). The collection from SCOPUS found 5 papers that duplicated the 23 studies identified by the experts. After removing the duplicates, we were left with 86 documents in total (expert panel and SCOPUS search combined) that we reviewed in full-text. In that stage of review, we excluded 40 studies because they did not or not sufficiently address farmers' demand, as defined in this study. This led to a selection of 46 studies that were further analysed.

\subsection{Data analysis}

In a first step of analysis, we coded the identified studies and analysed their content. We used the qualitative data analysis software MaxQDA Standard 2018 (release 18.2.0) to assist with the analysis of the 46 full-text studies, which included coding the content and categorising the downloaded documents. The following criteria were used to stratify and aggregate content for further analysis:

- the species of RTB crops, since the crop species has implications for the characteristics of planting material and how the seed system is organised;

- the country/countries in which the studies were applied in order to get insights on the regional coverage of studies;

- research methods, including data collection, stakeholder engagement and data analysis, which is a key aspect of our objectives in this review;

- aspects of demand to understand the relationship between the nature of demand and research methods used, and;
- claims made, and objectives addressed, in regard to farmers' demand for seed, which helped us to understand how the identified studies intended, and actually contributed, to articulating demand.

Based on coding the study content (objectives, main emphasis on the presented data, and conclusions of the study), we identified three main categories of studies. In an iterative process, we subsequently reviewed the studies in each category again to develop sub-categories of the classification scheme according to the research approaches used (Fig. 2). While consolidating the (sub-)categories of the scheme, we assigned each study to a respective sub-category. In cases when a study covered multiple categories or methodological groups, it was assigned to the one that was most prominently represented in the content of the study.

\section{Results}

\subsection{General characteristics of the identified literature}

We identified 46 literature sources that describe studies on farmers' demand for RTB seed. The majority $(n=40)$ were articles published in peer-reviewed journals. We also included project reports $(n=4)$, one baseline study and one MSc thesis that we received from our inquiry to the panel of experts. All the identified literature was published between 2003 and 2019 without a visible trend of increasing or decreasing numbers in this period (data not presented).

The most researched RTB crops for farmers' seed demand were potato and sweet potato (Fig. 1). The majority of studies $(n=41)$ were carried out in countries across Africa; we identified only three studies in Latin America and two in Asia. Our literature search did not find any articles relating to Europe and North America.

\subsection{Types of studies to understand farmers' demand}

When clustering the different literature sources, we arrived at different types of studies, which we used as categories and sub-categories (Fig. 2).

\subsubsection{Elicitation of farmers' varietal and seed preferences $(n=$ 17)}

We categorised 17 documents that reported studies that aimed to elicit farmers' preferences for varieties and their traits. We found three groups of research approaches that were used to do so: articulation of trait preferences, Means-End-Chain analysis and willingness to pay (WTP) studies. 


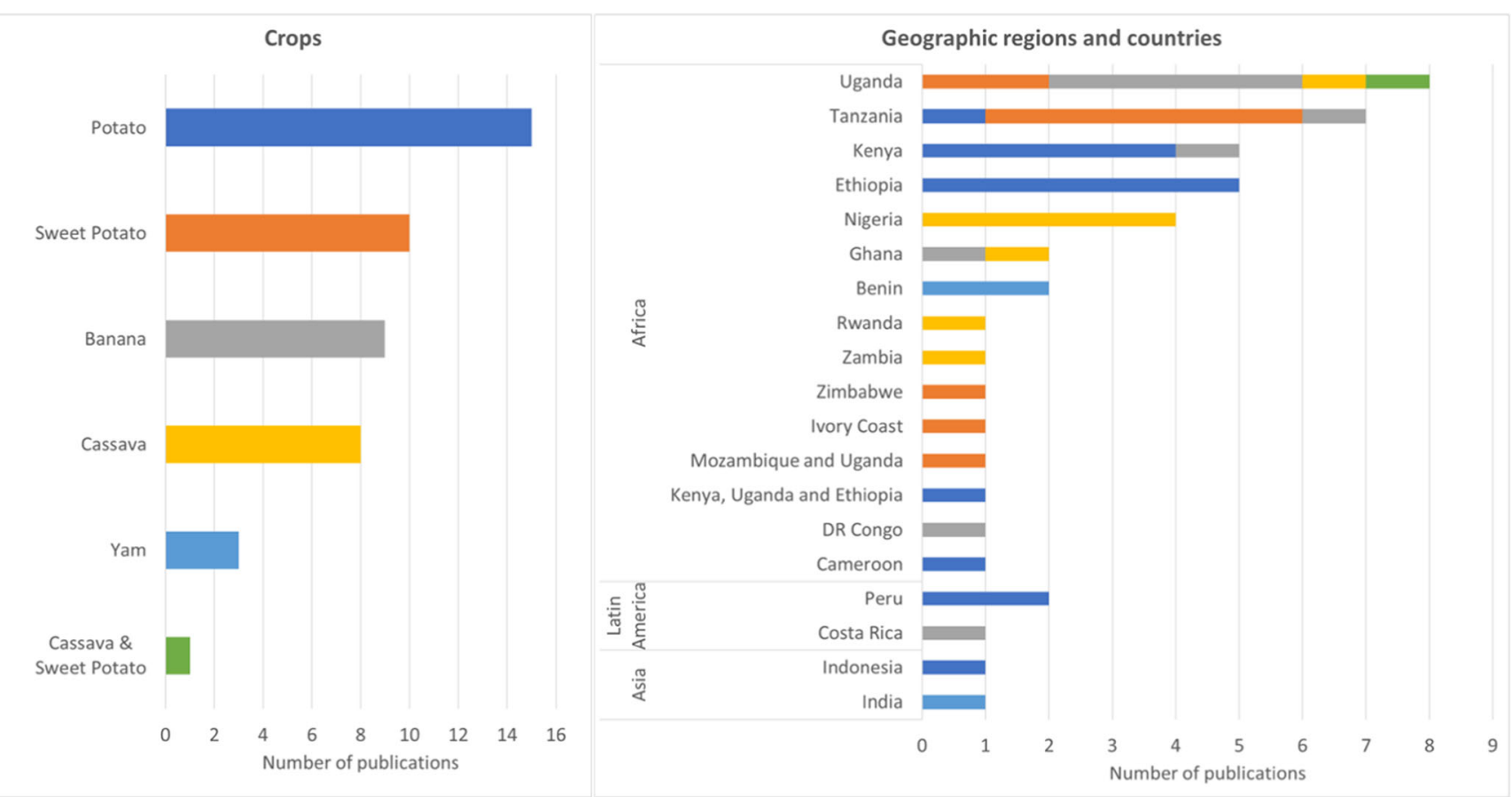

Fig. 1 Characterization of selected articles $(n=46)$ by RTB crops studied and regions and countries where studies were conducted, the colours representing the crops in the figure on the left correspond with the colours in the figure on the right (please see online version of this article for a colour version of this figure)
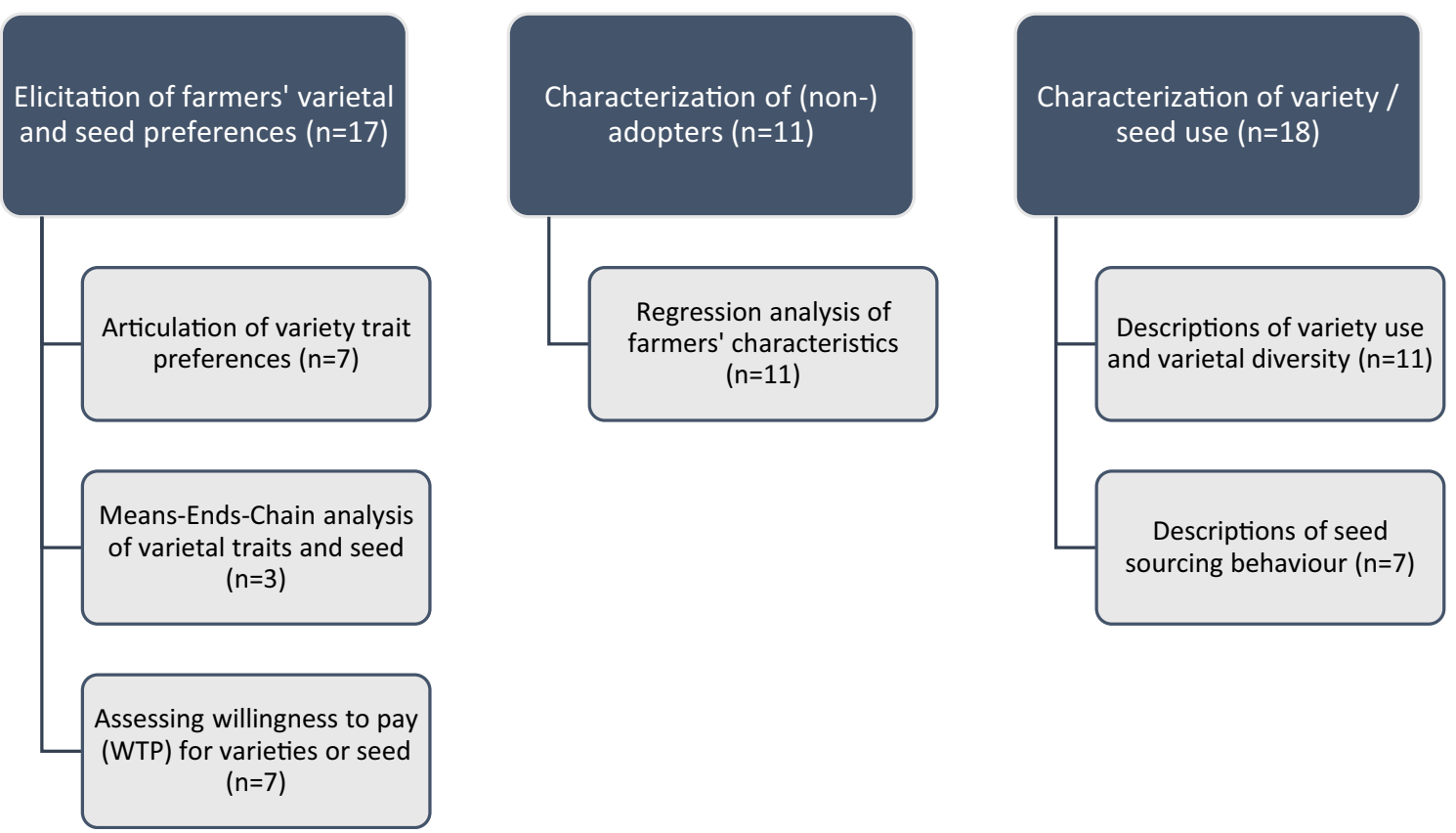

Fig. 2 Classification scheme of selected studies on farmers' demand for seed of RTB crops in different categories and sub-categories 
Articulation of variety trait preferences ( $n=7$, Table 2 ): We did not explicitly search for trait elicitation studies in this review, i.e. the term was not used in our request to the expert panel and neither in our SCOPUS search string. Yet as we reviewed the studies in our results, we found that some of them captured the variety preferences of farmers, consumers or processors. In this way they facilitated the articulation of farmers' demand for specific varietal attributes of RTB crops. The identified studies included banana, cassava, potato, sweet potato, and yam in Ethiopia, Ghana, India, Ivory Coast, Nigeria and Uganda. The research approaches varied. In four studies, farmers actively engaged in evaluating varieties in farmer and/or researcher managed trials (Dibi et al. 2017; Dzomeku et al. 2008; Kolech et al. 2019; Dixon et al. 2008). The other three studies elicited farmers' preferences by using pictures in combination with survey questions (Edmeades 2007), focus group discussions (FGDs) in combination with individual ranking of attributes on charts (Sivakumar Sethuraman et al. 2009) or with surveys (Kolech et al. 2019). Teeken et al. (2018) studied farmers' trait preferences by asking farmers about each variety that they were growing what particular traits motivated them to cultivate it. In three studies, researchers also carried out sensory tests in which farmers expressed their taste preferences (Dibi et al. 2017; Dixon et al. 2008; Edmeades 2007). The studies in this subcategory aimed to inform breeding programmes and in some cases did feed directly into a process of variety release (Dibi et al. 2017; Dixon et al. 2008). In addition to studying farmers' trait preferences, Edmeades et al. (2007) included farmers' selling behaviour in a hedonic price model to draw conclusions on whether variety improvement will pay off at the market level.

Means-Ends-Chain (MEC) analysis of varietal traits and seed $(n=3$, Table 3): Studies that used a MEC analysis aimed to better understand which traits of seeds or varieties farmers consider and the underlying motivations for preferring certain traits. The identified studies were all three from 2016 and later, done with potato in Peru, Kenya and Tanzania. Urrea-Hernandez et al. (2016) studied farmers' use of seed potato varieties in Peru with this method and paid attention to the attributes of seed tubers that farmers used to recognise seed of their preferred quality. The study compared farmers' perceptions of quality with those of formal experts in the seed system. Okello et al. (2018) carried out a MEC study as goal priming to find out why farmers invested in the seed of a new potato variety that was superior

Table 2 Identified literature articulating trait preferences through trials and/or with surveys and focus group discussions (FGDs)

\begin{tabular}{|c|c|c|c|c|}
\hline Reference & $\begin{array}{l}\text { Country } \\
\text { and crop }\end{array}$ & General focus of study & $\begin{array}{l}\text { Aspect } \\
\text { of } \\
\text { demand }\end{array}$ & $\begin{array}{l}\text { Research methods to } \\
\text { understand demand }\end{array}$ \\
\hline $\begin{array}{l}\text { Dibi et al. } \\
\text { (2017) }\end{array}$ & $\begin{array}{l}\text { Ivory } \\
\text { Coast, } \\
\text { sweet } \\
\text { potato }\end{array}$ & $\begin{array}{l}\text { Evaluated } 6 \text { varieties with women farmer groups to } \\
\text { recommend the most appreciated and best performing } \\
\text { one for release. All traits relevant to the women were } \\
\text { assessed. }\end{array}$ & $\begin{array}{c}\text { Varietal } \\
\text { traits }\end{array}$ & $\begin{array}{l}\text { Farmer managed plots }(n=8) \text {; participatory assessment } \\
\text { of crop characteristics and consumer preferences } \\
\text { (sensory evaluation) of } 6 \text { varieties }\end{array}$ \\
\hline $\begin{array}{l}\text { Dixon et al. } \\
\text { (2008) }\end{array}$ & $\begin{array}{l}\text { Nigeria, } \\
\text { cassa- } \\
\text { va }\end{array}$ & $\begin{array}{l}\text { Reported on a fast track evaluation of } 40 \text { cassava } \\
\text { cultivars that resulted in the release of } 17 \text { cassava } \\
\text { mosaic disease-resistant cultivars. }\end{array}$ & $\begin{array}{c}\text { Varietal } \\
\text { traits }\end{array}$ & $\begin{array}{l}\text { Over } 150 \text { farmers- and/or researcher-managed trials in } \\
\text { two growing seasons; participatory assessment of } \\
\text { crop characteristics and farmers' consumer prefer- } \\
\text { ences }\end{array}$ \\
\hline $\begin{array}{l}\text { Dzomeku } \\
\text { et al. } \\
\text { (2008) }\end{array}$ & $\begin{array}{l}\text { Ghana } \\
\text { banan- } \\
\text { a, }\end{array}$ & $\begin{array}{l}\text { Evaluated new hybrid varieties on-farm and assessed } \\
\text { their food qualities and consumer acceptability. The } \\
\text { study emphasises that peoples' food habits must be } \\
\text { considered when introducing new varieties. }\end{array}$ & $\begin{array}{c}\text { Varietal } \\
\text { traits }\end{array}$ & $\begin{array}{l}\text { A total of } 500 \text { farmers in two districts were involved in } \\
\text { on-farm testing of } 4 \text { new hybrid varieties alongside } \\
\text { with landraces on-farm, using individual survey in- } \\
\text { terviews and FGDs. }\end{array}$ \\
\hline $\begin{array}{l}\text { Edmeades } \\
\quad \text { et al. } \\
\quad(2007)\end{array}$ & $\begin{array}{l}\text { Uganda, } \\
\text { banana }\end{array}$ & $\begin{array}{l}\text { Explored the economic trade-offs between banana fruit } \\
\text { size, bunch size and fruit quality at the farm gate. The } \\
\text { study potentially informs about the economic value of } \\
\text { an improved trait in cultivar development. }\end{array}$ & $\begin{array}{c}\text { Varietal } \\
\text { traits }\end{array}$ & $\begin{array}{l}\text { Survey data }(n=540) \text { analysed with econometric } \\
\text { model; Farmers ranked varietal attributes based on } \\
\text { photos. }\end{array}$ \\
\hline $\begin{array}{l}\text { Kolech et al. } \\
\text { (2019) }\end{array}$ & $\begin{array}{r}\text { Ethiopia, } \\
\text { potato }\end{array}$ & $\begin{array}{l}\text { Studied which potato traits farmers consider most } \\
\text { important, and characterised the diversity to inform } \\
\text { breeding programs. Found variations in } \\
\text { agro-ecological zones, cropping seasons and market } \\
\text { access. }\end{array}$ & $\begin{array}{c}\text { Varietal } \\
\text { traits }\end{array}$ & $\begin{array}{l}\text { Farmer survey ( } n=321 \text { in six districts) and FGDs. } \\
\text { Participatory variety selection scheme to test } 9 \text { local } \\
\text { and } 3 \text { new varieties; Two (gender separated) } \\
\text { farmers' groups ranked varietal traits in different } \\
\text { growing stages. }\end{array}$ \\
\hline $\begin{array}{l}\text { Sivakumar } \\
\text { Sethuram- } \\
\text { an et al. } \\
\text { (2009) }\end{array}$ & $\begin{array}{l}\text { India, } \\
\text { yam }\end{array}$ & $\begin{array}{l}\text { Identified farmers' varietal preferences and found that } \\
\text { these are different in commercial production systems } \\
\text { and subsistence ones. Their purpose was to redefine } \\
\text { breeding objectives. }\end{array}$ & $\begin{array}{c}\text { Varietal } \\
\text { traits }\end{array}$ & $\begin{array}{l}\text { Observational methods and key informant interviews; } \\
\text { ranking exercise }(n=30) \text { of varietal production } \\
\text { attributes (displayed on charts) and sensory } \\
\text { evaluation. }\end{array}$ \\
\hline $\begin{array}{l}\text { Teeken et al. } \\
\text { (2018) }\end{array}$ & $\begin{array}{l}\text { Nigeria, } \\
\text { cassa- } \\
\text { va }\end{array}$ & $\begin{array}{l}\text { Examined trait and varietal preferences of men and } \\
\text { women cassava farmers and processors. They aimed } \\
\text { to inform priority setting in gender responsive } \\
\text { breeding programmes. }\end{array}$ & $\begin{array}{c}\text { Varietal } \\
\text { traits }\end{array}$ & $\begin{array}{l}\text { Mixed methods ( } 150 \text { semi-structured interviews and } 16 \\
\text { FGDs in } 8 \text { communities). Farmers ranked traits that } \\
\text { motivated them to cultivate different cassava varie- } \\
\text { ties. }\end{array}$ \\
\hline
\end{tabular}


Table 3 Identified literature on the Means-Ends-Chain analysis

\begin{tabular}{|c|c|c|c|c|}
\hline Reference & $\begin{array}{l}\text { Country } \\
\text { and crop }\end{array}$ & General focus of study & Aspect of demand & $\begin{array}{l}\text { Research methods to } \\
\text { understand demand }\end{array}$ \\
\hline $\begin{array}{l}\text { Okello et al. } \\
\text { (2018) }\end{array}$ & $\begin{array}{c}\text { Tanzania, } \\
\text { potato }\end{array}$ & $\begin{array}{l}\text { Studied the motivations of farmers in an auction that } \\
\text { used vouchers, invested in quality seed of a new } \\
\text { potato variety. They found that farmers expect to } \\
\text { attain particular benefits that lead to reaching their } \\
\text { personal life goals. }\end{array}$ & Varietal traits & $\begin{array}{l}\text { Means-End-Chains methodology } \\
\quad(n=45) \text {, disaggregated by gender }\end{array}$ \\
\hline $\begin{array}{l}\text { Okello et al. } \\
\text { (2019) }\end{array}$ & $\begin{array}{l}\text { Kenya, } \\
\text { potato }\end{array}$ & $\begin{array}{l}\text { Investigated what motivates smallholder farmers to } \\
\text { invest in certified potato seed (or not). It found that all } \\
\text { farmers are driven by life goals (having a good and } \\
\text { happy life) for which profit-making is a means, rather } \\
\text { than an end. }\end{array}$ & Quality of seed & $\begin{array}{l}\text { Means-End-Chains methodology, } \\
\text { disaggregated by gender and users / } \\
\text { non-users of certified seed }(n=96) \text {. }\end{array}$ \\
\hline $\begin{array}{l}\text { Urrea-Hernandez } \\
\text { et al. (2016) }\end{array}$ & $\begin{array}{l}\text { Peru, } \\
\text { potato }\end{array}$ & $\begin{array}{l}\text { Studied farmers' variety use and compared their } \\
\text { perceptions with those of formal experts. It found that } \\
\text { farmers pay attention to seed tuber traits that } \\
\text { researchers hardly consider. }\end{array}$ & $\begin{array}{c}\text { Varietal traits and } \\
\text { quality of seed }\end{array}$ & $\begin{array}{l}\text { Means-End-Chains methodology } \\
\quad(n=34)\end{array}$ \\
\hline
\end{tabular}

in quality than those available locally. Okello et al. (2019) applied MEC analysis to farmers use of quality (certified) seed by using disaggregated data for men/women and users/non-users of certified seed.

Assessing willingness to pay (WTP) for varieties or seed $(n=7$, Table 4): WTP studies were used to understand farmers' demand by relating it to the price that farmers are willing to pay for it. We identified WTP studies on orange fleshed sweet potato (OFSP) and potato in Indonesia, Kenya, Mozambique, Peru, Tanzania and Uganda, and one on banana in Costa Rica. The studies' approach to assessing farmers' WTP differed strongly. The studies reported by Arimond et al. (2010) and Labarta (2009)

Table 4 Identified literature assessing willingness to pay (WTP) for varieties and seed

\begin{tabular}{|c|c|c|c|c|}
\hline Reference & Country and crop & General focus of study & Aspect of demand & Research methods to understand demand \\
\hline $\begin{array}{l}\text { Aguilar and } \\
\text { Kohlmann } \\
\text { (2006) }\end{array}$ & $\begin{array}{l}\text { Costa Rica, banana } \\
\quad \text { (transgen.) }\end{array}$ & $\begin{array}{l}\text { Studied farm managers' willingness } \\
\text { to adopt a hypothetical transgenic } \\
\text { banana. }\end{array}$ & Varietal traits & $\begin{array}{l}\text { Survey with consumers }(n=101) \text { and farm } \\
\text { managers }(n=19) ; \text { probit regression }\end{array}$ \\
\hline $\begin{array}{l}\text { Arimond et al. } \\
\qquad(2010)^{*}\end{array}$ & $\begin{array}{l}\text { Mozambique and } \\
\text { Uganda, sweet } \\
\text { potato }\end{array}$ & $\begin{array}{l}\text { Determined how smallholders' WTP } \\
\text { for varying quantities of } \\
\text { disease-free planting material of } \\
\text { different sweet potato varieties. }\end{array}$ & $\begin{array}{l}\text { Varietal traits and } \\
\text { quantity of seed }\end{array}$ & Real choice experiment \\
\hline $\begin{array}{l}\text { Buijs et al. } \\
\text { (2005) }\end{array}$ & Peru, potato & $\begin{array}{l}\text { Identified farmers' WTP for a } \\
\text { hypothetical variety as well as the } \\
\text { opportunities to release GMO } \\
\text { potatoes in the region. }\end{array}$ & Varietal traits & Survey ( $n=500$ ), descriptive statistics \\
\hline $\begin{array}{l}\text { Fuglie et al. } \\
\text { (2006) }\end{array}$ & Indonesia, potato & $\begin{array}{l}\text { Calculated a seed price at which the } \\
\text { present value of added benefits } \\
\text { from using a seed source would } \\
\text { equal the added seed cost. }\end{array}$ & Quality of seed & $\begin{array}{l}\text { Survey }(n=182) \text { and calculation of demand } \\
\text { equation }\end{array}$ \\
\hline $\begin{array}{l}\text { Kaguongo et al. } \\
\text { (2014) }\end{array}$ & Kenya, potato & $\begin{array}{l}\text { Established the status of the seed } \\
\text { potato industry and evaluated the } \\
\text { use of high-quality seed. } \\
\text { Identified WTP for clean / certi- } \\
\text { fied seed and the explanatory } \\
\text { variables for paying for different } \\
\text { types of seed. }\end{array}$ & Quality of seed & $\begin{array}{l}\text { Survey }(n=1300) \text { with contingent valuation } \\
\text { method and econometric analysis }\end{array}$ \\
\hline Labarta (2009)* & $\begin{array}{l}\text { Mozambique, sweet } \\
\text { potato }\end{array}$ & $\begin{array}{l}\text { Determined smallholders' WTP for } \\
\text { sweet potato varieties and } \\
\text { disease-free planting material. }\end{array}$ & Varietal traits & $\begin{array}{l}\text { Real choice experiment and survey }(n=121) \text {, } \\
\text { mixed logit model }\end{array}$ \\
\hline Mwiti (2015) & Tanzania, sweet potato & $\begin{array}{l}\text { Identified WTP for certain sweet } \\
\text { potato varieties and factors that } \\
\text { affect willingness to pay. }\end{array}$ & Varietal traits & $\begin{array}{l}\text { Survey }(n=732) \text { with contingent valuation } \\
\text { method and econometric analysis }\end{array}$ \\
\hline
\end{tabular}

*Both studies were based on the Reaching End Users (REU) project and appear to overlap. While Arimond et al. (2010) summarized two WTP studies in Mozambique and Uganda, Labarta (2009) is a more detailed report of the study in Mozambique 
engaged farmers in a real choice experiment, in which farmers were given a small amount of money to spend (or not) in the study. The farmers could choose to buy one of the varieties - offered by the researchers- or opt not to buy. Labarta (2009) applied a mixed logit model to estimate farmers' marginal WTP and to evaluate the determinants of farmers' WTP for vines. Involving farmers in real-choice-experiments resulted in a so-called revealed preference for RTB planting materials.

The other identified studies used surveys to assess socalled stated preference: they asked farmers if they were willing to adopt a hypothetical variety or seed and/or how much they would be willing to pay for it (contingent valuation method). Researchers asked farmers the maximum amount they would pay for certified seed, clean seed, positively selected seed or farmer seed, respectively (Kaguongo et al. 2014), for different sweet potato varieties (Mwiti 2015) or for hypothetical, transgenic, insectresistant potato variety (Buijs et al. 2005) or for a transgenic banana variety that reduced pest management costs (Aguilar and Kohlmann 2006). Buijs et al. (2005) complemented the WTP study with a study on the conditions for deployment of genetically engineered potatoes in the region. Kaguongo et al. (2014) analysed the results with an econometric approach to identify variety and farmer specific factors that affect WTP. Fuglie et al. (2006) used farmers yield data to calculate the value of seed and considered this the potential WTP. The authors found that the calculated seed value was higher than the actual price of potato seed in the market.

The results from these WTP studies led to quite varied claims: farmers were willing to adopt GMO banana that would reduce pesticide costs at a WTP of USD 500-999 per ha (Aguilar and Kohlmann 2006). Buijs et al. (2005) calculated that if farmers were to pay a $25 \%$ premium price for the insect resistant potato variety, then they would increase their profits. Farmers' WTP indicated a market for decentralised vine multipliers (Labarta 2009). Fuglie et al. (2006) raised the expectation that seed sector investment could make quality seed available to farmers and benefit them by increasing productivity. Farmers apparently were aware of the value of higher quality seed (Kaguongo et al. 2014). Farmers' WTP was influenced by gender, age, distance to the nearest road and education (Mwiti 2015).

\subsubsection{Characterization of (non-)adopters $(n=11)$}

Another type of study we found are adoption studies ( $n=11$, Table 5 ), although we had not initially aimed to include them in this review, i.e. the term adoption was not included in the SCOPUS search string. We kept the studies because some of them provided information on farmers' acceptance of, and preference for varieties, albeit indirectly. Eight studies in this category focused on the adoption of improved varieties in all five main RTB crops in Africa (Abebe et al. 2013; Afolami et al. 2015; Deffo and Demo 2003; Edmeades et al. 2007; Nigussie et al. 2016; Tarawali et al. 2012). In addition, we identified studies on the adoption of planting material from rapid, disease-free propagation methods, such as tissue-culture bananas in Kenya (Wanyama et al. 2016) and tissue-culture sweet potatoes in Zimbabwe (Mutandwa et al. 2008), certified seed potatoes marketed by a private seed company in Kenya (Okello et al. 2016). While the majority of studies focused on the adoption of certain varieties, four of the identified studies (Abebe et al. 2013; Edmeades and Smale 2006; Okello et al. 2016; Wanyama et al. 2016) also studied the intensity of adoption; the amount of seed and area of land that adopting farmers used for cultivation.

The majority of the studies are based on surveys and use regression analyses (linear regression, logistic regression, probit regression) to relate farmer characteristics with the adoption and non-adoption of improved varieties and seeds. On this basis, the studies indirectly provided insights into the conditions under which farmers are willing to adopt a particular variety or type of seed. The results included socio-economic characteristics, geographical factors and access to advisory services as influences on adoption. Out of adoption and non-adoption, it was possible to distil information on farmers' preferences for particular varieties, seeds and their traits. Since the studies assessed farmers' revealed preferences, these studies cannot be used to understand the demand for varieties that farmers do not yet know or cultivate. In contrast, Deffo and Demo (2003) did not assess household characteristics, but analysed the adoption progress and farmers' reasons for (non-)adoption of four new potato varieties by applying descriptive statistics to survey data. Two studies by Edmeades and colleagues (Edmeades et al. 2008; Edmeades and Smale 2006) used novel modelling approaches by using the survey data to, respectively, characterise the households likely to adopt transgenic banana in Uganda and estimate the demand for banana variety traits.

\subsubsection{Characterization of variety / seed use $(n=19)$}

The largest group of studies characterises how farmers use varieties and seed within their farming contexts, in which RTB crops predominantly involved informal seed systems. We distinguished two sub-categories: one focusing more on the use of varieties and diversity and the other one on how farmers source and use seed. 
Table 5 Identified literature on the characterization of (non-)adopters via regression analyses of farmers' characteristics

\begin{tabular}{|c|c|c|c|c|}
\hline Reference & $\begin{array}{l}\text { Country and } \\
\text { crop }\end{array}$ & General focus of study & Aspect of demand & $\begin{array}{l}\text { Research methods to } \\
\text { understand demand }\end{array}$ \\
\hline Afolami et al. (2015) & Nigeria, cassava & $\begin{array}{l}\text { Identified the determinants of adoption and } \\
\text { studied the effects of adoption of improved } \\
\text { varieties on the welfare of households. } \\
\text { Found that the adoption of improved } \\
\text { varieties is pro-poor in nature. }\end{array}$ & Varietal traits & $\begin{array}{l}\text { Survey ( } n=312 \text { in } 2 \text { states); } \\
\quad \text { logistic regression }\end{array}$ \\
\hline Abebe et al. (2013) & Ethiopia, potato & $\begin{array}{l}\text { Identified the determinants of adoption in } \\
\text { relation to farmers' engagement with the } \\
\text { agricultural knowledge and innovation } \\
\text { system and their preferences for local } \\
\text { varieties. Also studied the intensity of } \\
\text { adoption. }\end{array}$ & $\begin{array}{l}\text { Varietal traits and quantity } \\
\text { of seed }\end{array}$ & $\begin{array}{l}\text { Survey }(n=346) \text {, ordered } \\
\text { probit model and treatment } \\
\text { effect (Heckman sample } \\
\text { selection) model }\end{array}$ \\
\hline $\begin{array}{l}\text { Deffo and Demo } \\
\text { (2003) }\end{array}$ & $\begin{array}{l}\text { Cameroon, } \\
\text { potato }\end{array}$ & $\begin{array}{l}\text { Explored the extent of adoption, and related } \\
\text { constraints, of two improved potato } \\
\text { varieties. Found that adoption was } \\
\text { constrained by the cultivars' susceptibility } \\
\text { to bacteria wilt and a lack of technical } \\
\text { assistance. }\end{array}$ & Varietal traits & $\begin{array}{l}\text { Survey }(n=297) \text {; descriptive } \\
\quad \text { statistics }\end{array}$ \\
\hline Edmeades et al. (2007) & $\begin{array}{r}\text { Tanzania, } \\
\text { banana }\end{array}$ & $\begin{array}{l}\text { Identified the determinants of adoption for } \\
\text { new banana varieties and made predictions } \\
\text { of the impact on farms adopting these } \\
\text { varieties. }\end{array}$ & Varietal traits & $\begin{array}{l}\text { Survey }(n=260) \text {; linear } \\
\quad \text { regression }\end{array}$ \\
\hline $\begin{array}{l}\text { Edmeades and Smale } \\
\text { (2006) }\end{array}$ & Uganda, banana & $\begin{array}{l}\text { Characterised agricultural households in } \\
\text { Uganda that are likely to influence the } \\
\text { adoption of transgenic varieties and } \\
\text { illustrated the sensitivity of farmer demand. }\end{array}$ & $\begin{array}{l}\text { Varietal traits, quantity of } \\
\text { seed }\end{array}$ & $\begin{array}{l}\text { Survey }(n=540) \text {; modelling } \\
\text { agricultural household } \\
\text { model }\end{array}$ \\
\hline Edmeades et al. (2008) & Uganda, banana & $\begin{array}{l}\text { Modelled farmers' varietal choices and } \\
\text { estimated the intensity of cultivating a } \\
\text { variety in case of adoption. Drew } \\
\text { implications for the social and economic } \\
\text { impacts of crop improvement. }\end{array}$ & Varietal traits & $\begin{array}{l}\text { Survey }(\mathrm{n}=540) \text {; Modelling } \\
\text { varietal choices and } \\
\text { demand }\end{array}$ \\
\hline $\begin{array}{l}\text { Mutandwa et al. } \\
\text { (2008) }\end{array}$ & $\begin{array}{l}\text { Zimbabwe, } \\
\text { sweet potato }\end{array}$ & $\begin{array}{l}\text { Identified the factors that affect adoption and } \\
\text { the impact of using tissue-cultured mate- } \\
\text { rials on productivity and incomes. }\end{array}$ & Quality of seed & $\begin{array}{l}\text { Survey }(n=133) \text { and } \\
\text { semi-structured interviews } \\
\text { with stakeholders; logistic } \\
\text { regression model }\end{array}$ \\
\hline Nigussie et al. (2016) & Ethiopia, potato & $\begin{array}{l}\text { Identified the determinants of adoption of } \\
\text { improved varieties (e.g. cooperative } \\
\text { membership, age, use of fertiliser). }\end{array}$ & Varietal traits & $\begin{array}{l}\text { Survey }(n=158) ; \text { logistic } \\
\quad \text { regression }\end{array}$ \\
\hline Okello et al. (2016) & $\begin{array}{l}\text { Kenya, sweet } \\
\text { potato }\end{array}$ & $\begin{array}{l}\text { Identified the factors determining the decision } \\
\text { to use certified seed potatoes and intensity } \\
\text { of use. They concluded that poverty } \\
\text { impedes the decision to adopt, and thus } \\
\text { benefit from, certified seed. }\end{array}$ & $\begin{array}{l}\text { Quality of seed, } \\
\text { quantity of seed }\end{array}$ & $\begin{array}{l}\text { Survey }(n=408) \text {; probit } \\
\quad \text { regression }\end{array}$ \\
\hline Tarawali et al. (2012) & Nigeria, cassava & $\begin{array}{l}\text { Identified determinants of adoption of } \\
\text { improved varieties (e.g. improved crop } \\
\text { management practices, gender, cassava } \\
\text { yield and farming experience). }\end{array}$ & Varietal traits & $\begin{array}{l}\text { Survey ( } n=68 \text { in } 8 \text { states); } \\
\text { probit model }\end{array}$ \\
\hline Wanyama et al. (2016) & Kenya, banana & $\begin{array}{l}\text { Identified determinants of adoption and the } \\
\text { intensity of use of tissue culture bananas } \\
\text { (e.g. the availability of seed, income, } \\
\text { location, family size, farm size). }\end{array}$ & $\begin{array}{l}\text { Quality of seed, } \\
\text { quantity of seed }\end{array}$ & $\begin{array}{l}\text { Survey ( } n=330 \text { in } 4 \text { counties); } \\
\text { double hurdle regression } \\
\text { model }\end{array}$ \\
\hline
\end{tabular}

Descriptions of variety use and varietal diversity $(n=11$, Table 6): These studies characterised the farmers' variety use and management to adapt to a context of history, agro-ecology, markets, and culture. The studies were generally motivated by wanting to understand the reasons why farmers continue to use certain (local) varieties and the dynamics in maintaining and managing variety diversity.
The identified studies provided empirical evidence on the influence of historical change of cassava farming in Ghana (Manu-Aduening et al. 2005), socio-cultural practices around yam in Benin (Zannou et al. 2004, 2007), farmers' resource endowments and associated farming practices for potato in Ethiopia (Tadesse et al. 2017), the constraints faced by farmers in cassava root production in 
Table 6 Identified literature describing variety use and varietal diversity

\begin{tabular}{|c|c|c|c|c|}
\hline Reference & $\begin{array}{l}\text { Country and } \\
\text { crop }\end{array}$ & General focus of study & Aspect of demand & $\begin{array}{l}\text { Research methods to } \\
\text { understand demand }\end{array}$ \\
\hline Adheka et al. (2018) & DRC, banana & $\begin{array}{l}\text { Assessed the diversity of varieties across one province to } \\
\text { provide knowledge on genetic diversity and } \\
\text { geographical spread. It found that farmers select } \\
\text { cultivars mostly because of their taste and market value, } \\
\text { and less because of high yield. }\end{array}$ & $\begin{array}{l}\text { Varietal traits, } \\
\text { quality of seed }\end{array}$ & $\begin{array}{l}\text { Group discussions in } 75 \\
\text { villages; survey }(n=750) \\
\text { across all the villages; } \\
\text { descriptive statistics }\end{array}$ \\
\hline $\begin{array}{l}\text { Chiwona-Karltun } \\
\text { et al. (2015) }\end{array}$ & $\begin{array}{l}\text { Zambia, } \\
\text { cassava }\end{array}$ & $\begin{array}{l}\text { Investigated the prevailing varietal preferences for leaves } \\
\text { and roots, based on the utilization as well as the } \\
\text { biochemical composition of local and recently } \\
\text { improved varieties. }\end{array}$ & Varietal traits & $\begin{array}{l}\text { Interviews with farmers and } \\
\text { researchers, ( } \mathrm{n} \text { is undefined) } \\
\text { chemical analysis of root } \\
\text { samples }\end{array}$ \\
\hline $\begin{array}{l}\text { Kilwinger et al. } \\
\text { (2019) }\end{array}$ & $\begin{array}{l}\text { Uganda, } \\
\text { banana }\end{array}$ & $\begin{array}{l}\text { Studied seed management and replacement by exploring } \\
\text { farmers' production objectives in relation to varietal } \\
\text { diversity, in order to understand the demand for banana } \\
\text { planting materials, and gain insights into farmers' } \\
\text { evaluation of planting materials and their quality } \\
\text { criteria. }\end{array}$ & $\begin{array}{l}\text { Varietal traits, } \\
\text { quality of seed }\end{array}$ & $\begin{array}{l}\text { Focus group discussions }(\mathrm{n}=4) \\
\text { and semi-structured inter- } \\
\text { views }(n=23) \text { in } 5 \text { villages } \\
\text { in } 2 \text { sub-counties, descrip- } \\
\text { tive statistics and qualitative } \\
\text { data analysis }\end{array}$ \\
\hline Kolech et al. (2015) & $\begin{array}{r}\text { Ethiopia, } \\
\text { potato }\end{array}$ & $\begin{array}{l}\text { Documented farmers' decision-making processes and the } \\
\text { external factors that influence variety diversity. The } \\
\text { authors called for greater consideration of variations in } \\
\text { agro-ecologies, cropping systems and market outlets in } \\
\text { order to develop varieties that meet farmers' needs. }\end{array}$ & Varietal traits & $\begin{array}{l}\text { Mixed methods; survey }(n= \\
60, \text { in } 6 \text { districts), key } \\
\text { informant interviews, } \\
\text { FGDs, field observations; } \\
\text { correlations, descriptive } \\
\text { statistics and qualitative } \\
\text { data analysis }\end{array}$ \\
\hline $\begin{array}{l}\text { Manu-Aduening } \\
\text { et al. (2005) }\end{array}$ & $\begin{array}{l}\text { Ghana, } \\
\text { cassava }\end{array}$ & $\begin{array}{l}\text { Explored the dynamics of farmers acquiring and } \\
\text { abandoning landraces over time; and the extent to } \\
\text { which they use seedlings for propagation. Due to the } \\
\text { slow evolution of landraces and the low adoption of } \\
\text { improved varieties in the communities, participatory } \\
\text { breeding programs were established. }\end{array}$ & Varietal traits & $\begin{array}{l}\text { Mixed methods; }(n=300) \text {, } \\
\text { key informant interviews, } \\
\text { FGDs; descriptive statistics, } \\
\text { statistical and qualitative } \\
\text { data analysis }\end{array}$ \\
\hline $\begin{array}{l}\text { Nakabonge et al. } \\
\text { (2018) }\end{array}$ & $\begin{array}{l}\text { Uganda, } \\
\text { cassava }\end{array}$ & $\begin{array}{l}\text { Explored how on-farm conservation of cassava germ- } \\
\text { plasm is influenced by farmers' traditional and cultural } \\
\text { preferences (e.g. culinary attributes, storability in the } \\
\text { ground, early maturity and cooking quality) of particu- } \\
\text { lar varieties. }\end{array}$ & Varietal traits & $\begin{array}{l}\text { Survey }(n=384) \text { in } 6 \\
\text { agro-ecological zones, de- } \\
\text { scriptive statistics. }\end{array}$ \\
\hline $\begin{array}{l}\text { Nduwumuremyi } \\
\text { et al. (2016) }\end{array}$ & $\begin{array}{l}\text { Rwanda, } \\
\text { cassava }\end{array}$ & $\begin{array}{l}\text { Identified the main constraints on cassava production, the } \\
\text { traits preferred by farmers, the effects of late bulking } \\
\text { cultivars, losses due to post-harvest physiological } \\
\text { deterioration, and factors affecting the adoption of new } \\
\text { genotypes. Informed breeding programs. }\end{array}$ & Varietal traits & $\begin{array}{l}\text { FGDs with farmers and } \\
\text { district officials; and } \\
\text { semi-structured interviews } \\
\text { with farmers, traders and } \\
\text { processors }(n=180) \\
\text { descriptive statistics }\end{array}$ \\
\hline $\begin{array}{l}\text { Tadesse et al. } \\
\text { (2017) }\end{array}$ & $\begin{array}{r}\text { Ethiopia, } \\
\text { potato }\end{array}$ & $\begin{array}{l}\text { Tried to find explanations for the low adoption of } \\
\text { improved potato cultivars through exploring potato } \\
\text { growing practices and their influence on farmer's } \\
\text { choice of varieties in different wealth groups. }\end{array}$ & Varietal traits & $\begin{array}{l}\text { Survey ( } n=47 \text {, disaggregated } \\
\text { wealth groups) and in-depth } \\
\text { interviews; descriptive sta- } \\
\text { tistics }\end{array}$ \\
\hline Zannou et al. (2004) & $\begin{array}{l}\text { Benin, } \\
\text { yam (and } \\
\text { cowpea) }\end{array}$ & $\begin{array}{l}\text { Analysed the importance of varieties and the influence of } \\
\text { the socio-cultural and local economic contexts on } \\
\text { maintaining diversity. The processes of loss and dis- } \\
\text { placement of some local varieties are described and the } \\
\text { need for conservation is addressed. }\end{array}$ & Varietal traits & $\begin{array}{l}\text { Mixed methods; survey }(\mathrm{n}= \\
\text { 40), key informant } \\
\text { interviews, FGDs; } \\
\text { statistical and qualitative } \\
\text { data analysis }\end{array}$ \\
\hline Zannou et al. (2007) & $\begin{array}{l}\text { Benin, } \\
\text { yam (and } \\
\text { cowpea) }\end{array}$ & $\begin{array}{l}\text { Elaborated on the cultural significance of the studied crops } \\
\text { in maintaining genetic diversity. The study shows that } \\
\text { the management of on-farm genetic resources is a so- } \\
\text { cially and culturally constructed system. }\end{array}$ & Varietal traits & $\begin{array}{l}\text { Survey }(n=521) \text {, participatory } \\
\text { characterization of planting } \\
\text { material; statistical analysis } \\
\text { and descriptive statistics }\end{array}$ \\
\hline $\begin{array}{l}\text { Zawedde et al. } \\
\text { (2014) }\end{array}$ & $\begin{array}{l}\text { Uganda, sweet } \\
\text { potato }\end{array}$ & $\begin{array}{l}\text { Assessed how the adoption of new cultivars and other } \\
\text { factors influenced varietal diversity. Farmers' criteria } \\
\text { for variety selection varied with a range of factors (e.g. } \\
\text { age, gender) that need to be considered for setting } \\
\text { breeding priorities and for diversity conservation. }\end{array}$ & Varietal traits & $\begin{array}{l}\text { Survey }(n=102) \text {, statistical } \\
\text { analysis and descriptive } \\
\text { statistics }\end{array}$ \\
\hline
\end{tabular}


Rwanda (Nduwumuremyi et al. 2016), variations in agroecologies, cropping systems and market outlets for potatoes in Ethiopia (Kolech et al. 2015), culinary preferences for cassava roots and leaves in Zambia (Chiwona-Karltun et al. 2015), the taste and market value of bananas in DR Congo (Adheka et al. 2018), and farmers' traditional and cultural preferences for using in different types of bananas in Uganda (Kilwinger et al. 2019; Nakabonge et al. 2018).

The studies used a mix of methods to collect the data: FGDs, open interviews, key informant interviews, surveys and transect walks. The results were mostly descriptive statistics combined with qualitative descriptions of use patterns. Kolech et al. (2015) also analysed the correlations between predominant varieties grown and the traits that farmers stated as important to them. Chiwona-Karltun et al. (2015) used chemical analyses of cassava root samples in addition to interviews to explain farmers' varietal preferences. While two of these articles aimed to explain why farmers are (not) adopting improved varieties that were being promoted in the study areas (Tadesse et al. 2017; Zawedde et al. 2014), the other nine studies informed how the interests of farmers in seed and varieties can be supported, e.g. with adapted breeding or diversity conservation programmes. The studies addressed varietal traits / genetic quality and, in two cases (Adheka et al. 2018; Kilwinger et al. 2019), additionally the quality of seed and associated seed management practices in order to explain varietal diversity.

Descriptions of seed sourcing behaviour $(n=7$, Table 7): Compared to the previous group of studies, this group had a stronger focus on understanding farmers' seed sourcing practices and their relationships with other actors in the seed system. The aspects of demand that were studied related either to the quantity or the quality of seed. Like the former group of studies, these used a mix of quantitative and qualitative methods, i.e. surveys, complemented with FGDs and/or key informant interviews.

The five studies in this group provided general descriptions of the varietal choices of farmers and their seed sourcing strategies. These studies aimed to understand potential entry points for (project facilitated) decentralised seed multipliers and seed marketing of sweet potato in Tanzania (Adam et al. 2018, Badstue and Adam 2011; Sindi, n.d.; Sindi and Wambugu 2012) and cassava and sweet potato in Uganda (Nangoti et al. 2004). In addition to characterising farmers' seed sourcing behaviour, Adam et al. (2018) and Badstue and Adam (2011) reported on the types of sweet potato vine transactions that occur among farmers and the roles that social relations and gender aspects play in this process. Kirimi Sindi (n.d.) complemented their findings by comparing the costs of production with farmers' willingness to pay, in order to estimate the potential for decentralised seed multipliers in the study areas.
Two other studies looked into the collective demand for seed in seed systems. Gildemacher et al. (2009) studied farmers' seed management and replacement in Kenya, Uganda and Ethiopia with a survey. Based on this information, they developed a model to calculate the demand for clean planting material in the potato seed systems in these countries. Kaguongo et al. (2009) assessed farmers' production practices and the potato seed system in Kenya in a large-scale survey to estimate the demand and supply of clean and certified seed potatoes and farmers' willingness to pay. Both studies informed seed system development (production, storage, marketing and distribution) in order to better address farmers' demand for quality seed.

\section{Discussion}

\subsection{Scope and types of identified studies}

Our approach of engaging a panel of experts enabled us to identify a wide range of studies that examine farmers' demand for RTB seed in one way or another. It was also helpful in formulating the search terms that could capture papers that fell within the desired scope of this research. The combination of the literature identified by the experts and our search covered a range of different scientific disciplines that addressed multiple aspects of demand for varieties and seeds. Overall, the number of studies is moderate: 46 studies over a period of 16 years on five RTB crops that have global importance for food security in developing countries. We are aware that we may have missed some publications in our literature search, and not all studies may have been published, but consultation with our panel confirmed that we had not overlooked initiatives that would change our results radically.

The iterative process of categorising these studies helped us to develop a classification scheme that identifies three main categories of studies (see Fig. 2). (i) Studies that articulate farmers' variety and seed preferences by actively engaging farmers. (ii) Studies that characterise (non-) adopters and identify determinants of farmers, households or farms that can be used to identify user groups that either opt for the adoption, or rejection, of particular varieties or types of seed. (iii) Studies that characterise farmers' varietal and seed use and sourcing behaviour to provide a contextualised or systemic characterization of farmers' demand for seed or varieties. We consider the first category as explicit demand articulation and the other two as implicit demand articulation, as discussed below.

\subsection{Explicit demand articulation}

In the studies that we categorised under Elicitation of farmers' variety and seed preferences, farmers were explicitly asked by researchers to express their interests in, and preferences for, varieties, varietal traits or types of seed. In general, these approaches 
Table 7 Identified literature describing seed sourcing behaviour

\begin{tabular}{|c|c|c|c|c|}
\hline Reference & Country and crop & General focus of study & $\begin{array}{l}\text { Aspect of } \\
\text { demand }\end{array}$ & $\begin{array}{l}\text { Research methods to } \\
\text { understand demand }\end{array}$ \\
\hline Adam et al. (2018) & $\begin{array}{l}\text { Tanzania, } \\
\text { sweet potato }\end{array}$ & $\begin{array}{l}\text { Studied farmers' sources of planting material; factors } \\
\text { that influence their sourcing of planting materials } \\
\text { from outside their own farms and the types of } \\
\text { transactions and social relations involved in farmers' } \\
\text { acquisition and distribution. }\end{array}$ & Seed sourcing & $\begin{array}{l}\text { Survey ( } n=621 \text { in } 9 \text { districts), } \\
\text { key informant interviews }(n= \\
28) \text { and FGDs }(n=6) ; \text { logistic } \\
\text { regression and qualitative } \\
\text { data analysis }\end{array}$ \\
\hline $\begin{array}{l}\text { Badstue and Adam } \\
\quad \text { (2011) } \\
\text { Project report } \\
\quad \text { (unpublished) }\end{array}$ & Tanzania, sweet potato & $\begin{array}{l}\text { Assessed the role of women in the management of } \\
\text { sweet potato vines. This paper provides specific } \\
\text { inputs into the discussion around the issues of gender } \\
\text { and local knowledge in relation to seed system } \\
\text { interventions. }\end{array}$ & $\begin{array}{l}\text { Quality of seed, } \\
\text { seed sourcing }\end{array}$ & $\begin{array}{l}\text { Semi-structured interviews with } \\
\text { women }(\mathrm{n}=29) \text { and } \\
\text { observation in contrasting } \\
\text { sites in the Lake Zone; } \\
\text { qualitative data analysis }\end{array}$ \\
\hline $\begin{array}{l}\text { Gildemacher et al. } \\
\text { (2009) }\end{array}$ & $\begin{array}{l}\text { Kenya, Uganda and } \\
\text { Ethiopia, } \\
\text { potato }\end{array}$ & $\begin{array}{l}\text { Analysed farmers' seed management and pest } \\
\text { management practices and calculated the demand for } \\
\text { clean planting material. Discussed opportunities for } \\
\text { seed system improvement. }\end{array}$ & $\begin{array}{l}\text { Quality of seed, } \\
\text { quantity of seed, } \\
\text { seed sourcing }\end{array}$ & $\begin{array}{l}\text { Disease analysis of potato fields } \\
\text { and seed, surveys ( } n=251 \text { in } \\
\text { Kenya, } n=144 \text { in Uganda, } \\
n=220 \text { in Ethiopia) }\end{array}$ \\
\hline $\begin{array}{l}\text { Kaguongo et al. (2009) } \\
\text { Project report (un- } \\
\text { published) }\end{array}$ & Kenya, potato & $\begin{array}{l}\text { Evaluated farmers' practices and their awareness of the } \\
\text { importance of clean/certified seed. Estimated the } \\
\text { demand and supply of clean/certified seed. } \\
\text { Highlighted opportunities to improve the seed value } \\
\text { chain. }\end{array}$ & $\begin{array}{l}\text { Quality of seed, } \\
\text { quantity of seed, } \\
\text { seed sourcing }\end{array}$ & $\begin{array}{l}\text { Survey }(n=1300) \text {; descriptive } \\
\text { statistics and regression }\end{array}$ \\
\hline Nangoti et al. (2004) & $\begin{array}{l}\text { Uganda, } \\
\text { cassava and sweet } \\
\text { potato }\end{array}$ & $\begin{array}{l}\text { Described seed sourcing behaviour, varietal } \\
\text { preferences, and seed management for a range of } \\
\text { crops. Discussed how interventions can address } \\
\text { various aspects of seed demand. }\end{array}$ & $\begin{array}{l}\text { Varietal traits, } \\
\text { seed sourcing }\end{array}$ & $\begin{array}{l}\text { Survey }(n=80) \text {, key informant } \\
\text { interviews and focus group } \\
\text { discussions }\end{array}$ \\
\hline $\begin{array}{l}\text { Sindi (n.d.) } \\
\text { Project report } \\
\quad \text { (unpublished) }\end{array}$ & Tanzania, sweet potato & $\begin{array}{l}\text { Characterised sources of seed, farmers' varietal } \\
\text { preferences and compared the costs of production } \\
\text { against farmers' willingness to pay, as an input to } \\
\text { project design. The study concluded that vine } \\
\text { production is commercially viable. }\end{array}$ & $\begin{array}{l}\text { Varietal traits / } \\
\text { genetic quality, } \\
\text { seed sourcing }\end{array}$ & $\begin{array}{l}\text { Survey ( } n=216 \text { ); descriptive } \\
\text { statistics }\end{array}$ \\
\hline $\begin{array}{l}\text { Sindi and Wambugu } \\
\text { (2012), Baseline } \\
\text { study (unpublished) }\end{array}$ & Tanzania, sweet potato & $\begin{array}{l}\text { Described farming practices, farmers' preferred } \\
\text { varieties and traits, and sourcing behaviour for vines } \\
\text { and the challenges associated with seed of sweet } \\
\text { potato. They conclude that there is a potential for } \\
\text { decentralised seed multipliers in the study areas. }\end{array}$ & $\begin{array}{l}\text { Varietal traits, } \\
\text { seed sourcing }\end{array}$ & $\begin{array}{l}\text { Survey ( } \mathrm{n}=621 \text { in } 9 \text { districts); } \\
\text { descriptive statistics }\end{array}$ \\
\hline
\end{tabular}

show an important limitation concerning novel technologies, such as a hypothetical variety with traits farmers have never heard of (i.e. biofortified varieties, GMO seeds), which do not have pre-defined markets, or which farmers have not yet been able to evaluate over a number of seasons in their own fields (Misiko 2013). In such a situation, it is doubtful that researchers will be able to define farmers' demand through surveying techniques (Orihata and Watanabe 2000). In some studies, researchers engaged with farmers through participation in the evaluation of field trials, auctions or choice experiments, sometimes even including taste tests. These approaches allowed farmers to familiarise themselves to some extent with the new varieties or seed and compare them, but they still have some serious limitations. The influence of the specific context of farmers that shapes their real-life preferences and trade-offs remain outside the trial evaluations and therefore may be hidden (Almekinders et al. 2019a). The Means-End-Chain approach may yield additional insights because of its openness, but does not pull in trade-offs with other livelihood activities. We might better understand the motivations and preferences of farmers through doing so, but we cannot characterise their demand and choices for seed beyond the experimental context.

\subsection{Implicit demand articulation}

We consider the second two groups of studies as being implicit forms of demand elicitation. Researchers studied farmers' adoption behaviour, seed management practices or the functioning of seed systems without directly asking farmers to express their preference for particular variety traits or demand for seed. These studies could, however, be used to distil particular aspects of demand through interpreting the findings.

The results of adoption studies mostly characterise the (non-)adopters ex-post, and relate this with characteristics such as age, gender, size of the farm and access to extension service. This information helps us to better understand the types of farmers that have an interest in certain varieties or types or seed. However, the majority of the studies in this category did not factor in how farmers used the specified type of seed or variety, e.g. the area of land they allocated to plant a new variety. Moreover, most of these studies did not pay specific attention to the traits that made varieties or seeds attractive or not. Thus, these studies do not create a deeper understanding of the reasons for, and conditions that influence, non-adoption: is it the variety, the availability or access of seed of the variety or the choice of the 
farmer? The simplified perspective of adoption is also reflected in the argument of Glover et al. (2019) and Sumberg (2016) that adoption data do not sufficiently explain the underlying process of farmers' technological change.

The final category of studies characterise how farmers currently use varieties and seeds. Studies that describe variety use and varietal diversity create a better understanding of how the dynamics of farming systems result in farmers' choices of varieties along with other technological choices. Descriptions of farmers' seed sourcing practices can lead to the identification of constraints and opportunities for farmers to access seed and new germplasm, and provide entry points for seed delivery programs to reach farmers with seed of improved varieties. While neither of the latter two types of studies directly inform us about farmers' demand for seed, they can be used to derive farmers' demand by interpreting their motivations for their current varietal choices and their seed sourcing practices. Representing farmers actual use of varieties and seeds, the results of these are generally very reliable and have a high external validity (see Breidert et al. 2006). The limitation of these approaches is that they do not necessarily point to constraints and potential improvements in seed or variety use. They can also not be used to study farmers' future demands for seed or their demand for varieties or types of seed that they do not know.

\section{Conclusions}

Our review has yielded a range of studies and approaches that all study aspects of farmers' demand for varieties and seeds. Each of them has its disciplinary angle and interpretation, and, consequently, its strengths and weaknesses. Yet it is worth asking whether and how the findings of these studies are being acted upon? Some studies were meant as baseline studies to inform project design and implementation or to inform breeding programs about farmers' preferences. However, the reasons why a large number of the studies were carried out remain unclear. Given the need for demand-driven innovation in seed systems, we consider the research we identified to be limited, and too diverse in set-up and approaches to be able to systematically inform breeders, seed suppliers and other actors who play a role in supporting seed system development.

While most studies aim to understand seed demand from the perspective of farmers, we should also consider the supply side. Both show a high degree of variability and unpredictability, coevolving in a process that includes multiple stakeholders from the demand and supply sides (Bentley et al. 2007). We recognise that the identified methods study farmers' demands of the here and now, whereas breeding programs and seed system interventions have to address future demands that can be influenced by market fluctuations, climate change and crisis situations. Due to these dynamics and unpredictability of demands over time and space, it is unlikely that a single method of demand articulation can provide a satisfactory basis for making seed systems more responsive to demand.

The conceptualization of demand and the classification scheme of methods for its articulation form a foundation for dealing with the multiple types and aspects of demand for RTB seed. Our classification scheme may guide researchers and development practitioners in reflecting on the methods they use or can use to study specific types and aspects of demand. Making the differences between these methods visible and considering their limitations is a first step in recognising the complexity of understanding farmers' demand. As a next step, we call for a comprehensive framework that purposefully combines these methods in order to understand the multiple demands of farmers, taking into account their real-life preferences and trade-offs. Using such a framework and involving farmers and other stakeholders in a demand articulation process would characterise existing demands in a more effective and precise way, thus providing better guidance to decision-makers in their reactions pertaining to seed systems.

Acknowledgements This research was undertaken as part of, and was partly funded by, the CGIAR Research Program on Roots, Tubers and Bananas (RTB) and supported by NWO-WOTRO and the CGIAR Fund Donors: http://www.cgiar.org/about-us/our-funders. We thank Peter Tamas for the methodological guidance in systematic literature review, the participants of the expert panel for their valuable inputs to this study and Nicholas Parrott for improving the English language content. We also thank the anonymous reviewers and the editor of this journal for carefully reading the manuscript and their helpful comments.

Author contributions Thomas Pircher and Conny Almekinders both conceptualized the literature review, analysed the identified literature and wrote the manuscript.

Funding Open Access funding was enabled and organized by Projekt DEAL. The research was partially funded by the NWO (www.nwo.nl) and the CGIAR Research Program on Roots, Tubers and Bananas (RTB) and supported by CGIAR Fund Donors: http://www.cgiar.org/about-us/ our-funders.

Data availability Data that is not presented in the article is available on request.

Code availability not applicable.

\section{Declarations}

Ethics approval not applicable.

Consent to participate Informed consent was obtained from all members of the expert panel.

Consent for publication Informed consent was obtained from all members of the expert panel.

Conflict of interest The authors declare that they have no conflict of interest. 
Open Access This article is licensed under a Creative Commons Attribution 4.0 International License, which permits use, sharing, adaptation, distribution and reproduction in any medium or format, as long as you give appropriate credit to the original author(s) and the source, provide a link to the Creative Commons licence, and indicate if changes were made. The images or other third party material in this article are included in the article's Creative Commons licence, unless indicated otherwise in a credit line to the material. If material is not included in the article's Creative Commons licence and your intended use is not permitted by statutory regulation or exceeds the permitted use, you will need to obtain permission directly from the copyright holder. To view a copy of this licence, visit http://creativecommons.org/licenses/by/4.0/.

\section{References}

Abebe, G. K., Bijman, J., Pascucci, S., \& Omta, O. (2013). Adoption of improved potato varieties in Ethiopia: The role of agricultural knowledge and innovation system and smallholder farmers' quality assessment. Agricultural Systems, 122, 22-32. https://doi.org/10. 1016/j.agsy.2013.07.008.

Adam, R. I., Badstue, L., \& Sindi, K. (2018). The dynamics of smallholder farmers' acquisition and distribution of sweetpotato vines in the Lake Victoria zone region, Tanzania. Food Security, 10, 339350. https://doi.org/10.1007/s12571-018-0776-5.

Adheka, J., Komoy, J., Tamaru, C., Sivirahauma, C., Dhed, D. B., Karamura, D., De Langhe, E., Swennen, R., \& Blomme, G. (2018). Banana diversity in the oriental provinces, northeastern Democratic Republic of Congo. Acta Horticulturae, 1196, 255264. https://doi.org/10.17660/ActaHortic.2018.1196.31.

Afolami, C. A., Obayelu, A. E., \& Vaughan, I. I. (2015). Welfare impact of adoption of improved cassava varieties by rural households in South Western Nigeria. Agricultural and Food Economics, 3(1). https://doi.org/10.1186/s40100-015-0037-2.

Aguilar, F. X., \& Kohlmann, B. (2006). Willingness to consume and produce transgenic bananas in Costa Rica. International Journal of Consumer Studies, 30(6), 544-551. https://doi.org/10.1111/j. 1470-6431.2006.00527.x.

Almekinders, C. J. M., Beumer, K., Hauser, M., Misiko, M., Gatto, M., Nkurumwa, A. O., \& Erenstein, O. (2019a). Understanding the relations between farmers' seed demand and research methods: The challenge to do better. Outlook on Agriculture, 48(1), 16-21.

Almekinders, C. J. M., \& Elings, A. (2001). Collaboration of farmers and breeders: Participatory crop improvement in perspective. Euphytica, 122(3), 425-438. https://doi.org/10.1023/A:1017968717875.

Almekinders, C. J. M., Louwaars, N. P., \& de Bruijn, G. H. (1994). Local seed systems and their importance for an improved seed supply in developing countries. Euphytica, 78(3), 207-216. https://doi.org/10. 1007/BF00027519.

Almekinders, C. J. M., Walsh, S., Jacobsen, K. S., Andrade-Piedra, J. L., McEwan, M. A., de Haan, S., Kumar, L., \& Staver, C. (2019b). Why interventions in the seed systems of roots, tubers and bananas crops do not reach their full potential. Food Security, 11(1), 23-42. https:// doi.org/10.1007/s12571-018-0874-4.

Arimond, M., Ballb, A., Béchoffc, A., Boschd, D., Howarth Bouisb, Brauwa, A. de Cootec C., Dovee, R, Eozenoub, P., Gilligana, D., Hotzb, C., Kumara, N., Labartaf, R., Loechlf, C., Lowf, J., Magezig, S., Massinguec, J., Meenakshib, J. V., Moursib, M., ... Westby, A. (2010). Reaching and Engaging End Users (REU) Orange Fleshed Sweet Potato (OFSP) in East and Southern Africa. In Final project report, HarvestPlus.

Badstue, L., \& Adam, R. (2011). Gender and vines: Production, management and exchange of sweetpotato planting material among smallholders in the Lake Victoria region, Tanzania. Technical Report, Helen Keller International, 35 p.

Bentley, J., Velasco, C., Rodríguez, F., Oros, R., Botello, R., Webb, M., Devaux, A., \& Thiele, G. (2007). Unspoken demands for farm technology. International Journal of Agricultural Sustainability, 5(1), 70-84. https://doi.org/10.1080/14735903.2007.9684814.

Boon, W. P. C. (2008). Demanding Dynamics. Demand Articulation of Intermediary Organisations in Emerging Pharmaceutical Innovations. Utrecht University, $\mathrm{PhD}$ Thesis.

Boon, W. P. C., \& Edler, J. (2018). Demand, challenges, and innovation. Making sense of new trends in innovation policy. Science and Public Policy, 45(4), 435-447. https://doi.org/10.1093/SCIPOL/ SCY014.

Boon, W. P. C., Moors, E. H. M., Kuhlmann, S., \& Smits, R. E. H. M. (2011). Demand articulation in emerging technologies: Intermediary user organisations as co-producers? Research Policy, 40(2), 242252. https://doi.org/10.1016/j.respol.2010.09.006.

Breidert, C., Hahsler, M., \& Reutterer, T. (2006). A review of methods for measuring willingness-to-pay. Innovative Marketing, 2(4), 8-32.

Buijs, J., Martinet, M., De Mendiburu, F., \& Ghislain, M. (2005). Potential adoption and management of insect-resistant potato in Peru, and implications for genetically engineered potato. Environmental Biosafety Research, 4(3), 179-188. https://doi.org/ 10.1051/ebr:2006002.

Ceccarelli, S., \& Grando, S. (2007). Decentralized-participatory plant breeding: An example of demand driven research. Euphytica, 155(3), 349-360. https://doi.org/10.1007/s10681-006-9336-8.

Ceccarelli, S., \& Grando, S. (2019). Participatory plant breeding: Who did it, who does it and where? Experimental Agriculture, 56, 1-11. https://doi.org/10.1017/S0014479719000127.

CGIAR. (2020). CGIAR 2030 Research and innovation strategy - draft 15 October 2020. https://www.cgiar.org/draft-cgiar-2030-researchand-innovation-strategy-and-performance-and-resultsmanagement-framework/

Chambers, R., Pacey, A., \& Thrupp, L. A. (1989). Farmer first: Farmer innovation and agricultural research. Intermediate Technology Publications.

Chiwona-Karltun, L., Nyirenda, D., Mwansa, C. N., Kongor, J. E., Brimer, L., Haggblade, S., \& Afoakwa, E. O. (2015). Farmer preference, utilization, and biochemical composition of improved cassava (Manihot esculenta Crantz) varieties in southeastern Africa. Economic Botany, 69(1), 42-56. https://doi.org/10.1007/s12231015-9298-7.

Deffo, V., \& Demo, P. (2003). Adoption of two new potato varieties in Cameroon: Progress and constraints. American Journal of Potato Research, 80(4), 263-269. https://doi.org/10.1007/BF02855362.

Dibi, K. E. B., Essis, B. S., N'Zué, B., Kouakou, A. M., Zohouri, G. P., Assouan, A. B., \& Van Mourik, T. (2017). Participatory selection of orange-fleshed sweetpotato varieties in north and north-east Côte d'Ivoire. Open Agriculture, 2(1), 83-90. https://doi.org/10.1515/ opag-2017-0009.

Dixon, A. G. O., Akoroda, M. O., Okechukwu, R. U., Ogbe, F., Ilona, P., Sanni, L. O., Ezedinma, C., Lemchi, J., Ssemakula, G., Yomeni, M. O., Okoro, E., \& Tarawali, G. (2008). Fast track participatory approach to release of elite cassava genotypes for various uses in Nigeria's cassava economy. Euphytica, 160(1), 1-13. https://doi. org/10.1007/s10681-007-9487-2.

Dzomeku, B. M., Armo-Annor, F., Adjei-Gyan, K., Ansah, J., Nkakwa, A., \& Darkey, S. K. (2008). On-farm evaluation and consumer acceptability study of selected Tetraploid Musa hybrid in Ghana. Journal of Plant Sciences, 3(3), 2016-2223. https://doi.org/10. 3923/jps.2008.216.223.

Edmeades, S. (2007). A hedonic approach to estimating the supply of variety attributes of a subsistence crop. Agricultural Economics, 37(1), 19-28. https://doi.org/10.1111/j.1574-0862.2007.00219.x. 
Edmeades, S., Nkuba, J. M., \& Smale, M. (2007). Use of hybrid cultivars in Kagera region, Tanzania, and their impact. In M. Smale \& W. Tushemereirwe (Eds.), An Economic Assessment of Banana Genetic Improvement and Innovation in the Lake Victoria Region of Uganda and Tanzania (pp. 129-140). IFPRI research report 155.

Edmeades, S., Phaneuf, D. J., \& Smale, M. (2008). Modelling the crop variety demand of semi-subsistence households: Bananas in Uganda. Journal of Agricultural Economics, 59(2), 329-349. https://doi.org/10.1111/j.1477-9552.2007.00153.x.

Edmeades, S., \& Smale, M. (2006). A trait-based model of the potential demand for a genetically engineered food crop in a developing economy. Agricultural Economics, 35(3), 351-361. https://doi.org/ 10.1111/j.1574-0862.2006.00167.x.

Fuglie, K. O., Adiyoga, W., Asmunati, R., Mahalaya, S., \& Suherman, R. (2006). Farm demand for quality potato seed in Indonesia. Agricultural Economics, 35(3), 257-266. https://doi.org/10.1111/j. 1574-0862.2006.00160.x.

Gildemacher, P. R., Demo, P., Barker, I., Kaguongo, W., Woldegiorgis, G., Wagoire, W. W., Wakahiu, M., Leeuwis, C., \& Struik, P. C. (2009). A description of seed potato systems in Kenya, Uganda and Ethiopia. American Journal of Potato Research, 86(5), 373-382. https://doi.org/10.1007/s12230-009-9092-0.

Glover, D., Sumberg, J., Ton, G., Andersson, J., \& Badstue, L. (2019). Rethinking technological change in smallholder agriculture. Outlook on Agriculture, 003072701986497, 169-180. https://doi. org/10.1177/0030727019864978.

Godin, B., \& Lane, J. P. (2013). Pushes and pulls: Hi(S)tory of the demand pull model of innovation. Science Technology and Human Values, 38(5), 621-654. https://doi.org/10.1177/ 0162243912473163.

Kaguongo, W., Maingi, G., Barker, I., Nganga, N., \& Guenthner, J. (2014). The value of seed potatoes from four Systems in Kenya. American Journal of Potato Research, 91(1), 109-118. https://doi. org/10.1007/s12230-013-9342-z.

Kaguongo, W., Nganga, N., \& Landeo, J. (2009). Seed potato use and projected demand in Kenya. Preliminary Report, $45 \mathrm{p}$.

Kilelu, C. W., Klerkx, L., \& Leeuwis, C. (2014). How dynamics of learning are linked to innovation support services: Insights from a smallholder commercialization project in Kenya. Journal of Agricultural Education and Extension, 20(2), 213-232. https://doi. org/10.1080/1389224X.2013.823876.

Kilwinger, F. B. M., Rietveld, A. M., Groot, J. C. J., \& Almekinders, C. J. M. (2019). Culturally embedded practices of managing banana diversity and planting material in Central Uganda. Journal of Crop Improvement, 33(4), 456-477. https://doi.org/10.1080/15427528. 2019.1610822

Klerkx, L., de Grip, K., \& Leeuwis, C. (2006). Hands off but strings attached: The contradictions of policy-induced demand-driven agricultural extension. Agriculture and Human Values, 23(2), 189-204. https://doi.org/10.1007/s10460-005-6106-5.

Klerkx, L., \& Leeuwis, C. (2008). Balancing multiple interests: Embedding innovation intermediation in the agricultural knowledge infrastructure. Technovation, 28(6), 364-378. https://doi.org/10. 1016/j.technovation.2007.05.005.

Kolech, S. A., De Jong, W., Halseth, D., \& Schulz, S. (2019). Understanding farmer needs and unlocking local genetic resources for potato improvement: A case study in Ethiopia. African Journal of Food, Agriculture, Nutrition and Development, 19(1), 1388313905. https://doi.org/10.18697/AJFAND.84.BLFB1012.

Kolech, S. A., Halseth, D., De Jong, W., Perry, K., Wolfe, D., Tiruneh, F. M., \& Schulz, S. (2015). Potato variety diversity, determinants and implications for potato breeding strategy in Ethiopia. American Journal of Potato Research, 92(5), 551-566. https://doi.org/10. 1007/s12230-015-9467-3.

Labarta, R. A. (2009). Are small Sub-Sahara African farmers willing to pay for vegetative propagated orange fleshed sweetpotato planting material? Evidence from Central Mozambique. Agricultural \& Applied Economics Association 2009 AAEA \& ACCI joint annual meetings, Milwaukee, Wisconsin, July 26-29 2009. https://core.ac. uk/download/pdf/6522660.pdf

Leeuwis, C., \& van den Ban, A. (2004). Communication for rural development. In In Communication for Rural Innovation: Rethinking Agricultural Extension. Science. Loeber: Blackwell.

Louwaars, N. P., \& De Boef, W. S. (2012). Integrated seed sector development in Africa: A conceptual framework for creating coherence between practices, programs, and policies. Journal of Crop Improvement, 26, 39-59. https://doi.org/10.1080/15427528.2011. 611277.

Manu-Aduening, J. A., Lamboll, R. I., Dankyi, A. A., \& Gibson, R. W. (2005). Cassava diversity in Ghanaian farming systems. Euphytica, 144(3), 331-340. https://doi.org/10.1007/s10681-005-8004-8.

McGuire, S., \& Sperling, L. (2011). The links between food security and seed security: Facts and fiction that guide response. Development in Practice, 21(4-5), 493-508. https://doi.org/10.1080/09614524. 2011.562485.

McGuire, S., \& Sperling, L. (2016). Seed systems smallholder farmers use. Food Security, 8(1), 179-195. https://doi.org/10.1007/s12571015-0528-8.

McMeekin, A., Tomlinson, M., Green, K., \& Walsh, V. (2002). Innovation by demand an interdisciplinary approach to the study of demand and its role in innovation. Manchester University Press.

Misiko, M. (2013). Dilemma in participatory selection of varieties. Agricultural Systems, 119, 35-42. https://doi.org/10.1016/j.agsy. 2013.04.004.

Mowery, D., \& Rosenberg, N. (1979). The influence of market demand upon innovation: A critical review of some recent empirical studies. Research Policy, 8(2), 102-153.

Mutandwa, E., Gadzirayi, C. T., \& Chihiya, J. (2008). Adoption of conventional biotechnology under declining smallholder crop productivity: Case of tissue cultured sweet potatoes. Quarterly Journal of International Agriculture, 47(4), 327-342.

Mwiti, F. K. (2015). Assessment of willingness to pay for quality sweetpotato planting materials: The case of smallholder farmers in Tanzania. MSc Thesis: University of Nairobi.

Nakabonge, G., Samukoya, C., \& Baguma, Y. (2018). Local varieties of cassava: Conservation, cultivation and use in Uganda. Environment, Development and Sustainability, 20(6), 2427-2445. https://doi.org/ 10.1007/s10668-017-9997-6.

Nangoti, N., Kayobyo, G., \& Rees, D. J. (2004). Seed demand and supply in northern and eastern Uganda: Implications for government and non-government interventions. Uganda Journal of Agricultural Sciences, 9, 778-784.

Nduwumuremyi, A., Melis, R., Shanahan, P., \& Asiimwe, T. (2016). Participatory appraisal of preferred traits, production constraints and postharvest challenges for cassava farmers in Rwanda. Food Security, 8(2), 375-388. https://doi.org/10.1007/s12571-016-0556$\mathrm{z}$.

Nigussie, Z., Alemayehu, G., Adgo, E., Tewodros, Y., \& Freyer, B. (2016). Reasons for acceptance of improved potato varieties by smallholder producers. International Journal of Vegetable Science, 22(4), 346-352. https://doi.org/10.1080/19315260.2015.1048402.

O'Sullivan, A., \& Sheffrin, S. M. (2003). Economics: Principles in action. In Pearson Prentice Hall. 0131334832.

Okello, J. J., Lagerkvist, C. J., Kakuhenzire, R., Parker, M., \& SchulteGeldermann, E. (2018). Combining means-end chain analysis and goal-priming to analyze Tanzanian farmers' motivations to invest in quality seed of new potato varieties. British Food Journal, 120(7), 1430-1445. https://doi.org/10.1108/BFJ-11-2017-0612.

Okello, J. J., Zhou, Y., Barker, I., \& Schulte-Geldermann, E. (2019). Motivations and mental models associated with smallholder farmers' adoption of improved agricultural technology: Evidence from use of quality seed potato in Kenya. European Journal of 
Development Research, 31(2), 271-292. https://doi.org/10.1057/ s41287-018-0152-5.

Okello, J. J., Zhou, Y., Kwikiriza, N., Ogutu, S. O., Barker, I., SchulteGeldermann, E., Atieno, E., \& Ahmed, J. T. (2016). Determinants of the use of certified seed potato among smallholder farmers: The case of potato growers in central and eastern Kenya. Agriculture, 6(4). https://doi.org/10.3390/agriculture6040055.

Okonya, J. S., Ocimati, W., Nduwayezu, A., Kantungeko, D., Niko, N., Blomme, G., Legg, J. P., \& Kroschel, J. (2019). Farmer reported pest and disease impacts on root, tuber, and banana crops and livelihoods in Rwanda and Burundi. Sustainability (Switzerland), 11(6), 1-20. https://doi.org/10.3390/su11061592.

Olum, S., Gellynck, X., Juvinal, J., Ongeng, D., \& De Steur, H. (2019). Farmers' adoption of agricultural innovations: A systematic review on willingness to pay studies. Outlook on Agriculture, 49(3), 187203. https://doi.org/10.1177/0030727019879453.

Orihata, M., \& Watanabe, C. (2000). Interaction between product concept and institutional inducement: A new driver of product innovation. Technovation, 20(1), 11-23. https://doi.org/10.1016/S01664972(99)00107-8.

Peine, A., \& Herrmann, A. M. (2012). The sources of use knowledge: Towards integrating the dynamics of technology use and design in the articulation of societal challenges. Technological Forecasting and Social Change, 79(8), 1495-1512. https://doi.org/10.1016/j. techfore.2012.04.014.

RTB. (2021). About RTB - CGIAR Reserach Program on Roots, Tubers and Bananas. Retrieved from https://www.rtb.cgiar.org/about/. Accessed 10 Jan 2021.

Savary, S., Akter, S., Almekinders, C., Harris, J., Korsten, L., Rötter, R., Waddington, S., \& Watson, D. (2020). Mapping disruption and resilience mechanisms in food systems. Food Security, 12(4), 695-717. https://doi.org/10.1007/s12571-020-01093-0.

Sindi, K. (n.d.). Tanzania mini - survey report understanding sweet potato seed system in Tanzania (41 p). Unpublished Project Report.

Sindi, K., \& Wambugu, S. (2012). Going-to-scale with sweetpotato vines distribution in Tanzania. Marando Bora Baseline Study. Project Report, International Potato Center (CIP), Nairobi, $49 \mathrm{p}$.

Sivakumar Sethuraman, P., Nedunchezhiyan, M., Paramaguru, S., \& Ray, R. C. (2009). Production system-specific differences in farmers' demand for greater yam (Dioscorea alata) varietal attributes in Orissa state, India. Experimental Agriculture, 45(4), 469-482. https://doi.org/10.1017/S0014479709990433.

Sperling, L., Ashby, J. A., Smith, M. E., Weltzien, E., \& Mcguire, S. (2001). Participatory plant breeding : A framework for analyzing diverse approaches. Euphytica, 122, 439-450. https://doi.org/10. 1023/A:1017505323730.

Spielman, D. J., \& Mekonnen, D. (2013). Transforming demand assessment in supply responses in Ethiopia's seed system and market. Prepared for the Agricultural Transformation Agency.

Sumberg, J. (2016). Opinion: The effects of technology adoption on food security: Linking methods, concepts and data. Food Security, 8(6), 1037-1038. https://doi.org/10.1007/s12571-016-0626-2.

Sumberg, J., \& Reece, D. (2004). Agricultural research through a 'new product development' lens. Experimental Agriculture, 40(3), 295 314. https://doi.org/10.1017/s0014479704002030.

Tadesse, Y., Almekinders, C. J. M., Schulte, R. P. O., \& Struik, P. C. (2017). Understanding farmers' potato production practices and use of improved varieties in Chencha, Ethiopia. Journal of Crop Improvement, 31(5), 673-688. https://doi.org/10.1080/15427528. 2017.1345817.

Tarawali, G., Iyangbe, C., Udensi, U. E., Ilona, P., Osun, T., Okater, C., \& Asumugha, G. N. (2012). Commercial-scale adoption of improved cassava varieties: A baseline study to highlight constraints of large-scale cassava based agro-processing industries in southern Nigeria. Journal of Food, Agriculture and Environment, 10(3-4), 689-694.
Teeken, B., Olaosebikan, O., Haleegoah, J., Oladejo, E., Madu, T., Bello, A., Parkes, E., Egesi, C., Kulakow, P., Kirscht, H., \& Tufan, H. A. (2018). Cassava trait preferences of men and women farmers in Nigeria: Implications for breeding. Economic Botany, 72(3), 263 277. https://doi.org/10.1007/s12231-018-9421-7.

Teubal, M., \& Twiss, B. C. (1979). On user needs and need Determination: Aspects of the Theory of Technological Innovation. In Industrial Innovation. https://doi.org/10.1007/9781-349-03822-0 14.

Thomas-Sharma, S., Abdurahman, A., Ali, S., Andrade-Piedra, J. L., Bao, S., Charkowski, A. O., Crook, D., Kadian, M., Kromann, P., Struik, P. C., Torrance, L., Garrett, K. A., \& Forbes, G. A. (2016). Seed degeneration in potato: The need for an integrated seed health strategy to mitigate the problem in developing countries. Plant Pathology, 65(1), 3-16. https://doi.org/10.1111/ppa.12439.

Thomas-Sharma, S., Andrade-Piedra, J., Carvajal Yepes, M., Hernandez Nopsa, J. F., Jeger, M. J., Jones, R. A. C., Kromann, P., Legg, J. P., Yuen, J., Forbes, G. A., \& Garrett, K. A. (2017). A risk assessment framework for seed degeneration: Informing an integrated seed health strategy for vegetatively propagated crops. Phytopathology, 107(10), 1123-1135. https://doi.org/10.1094/PHYTO-09-16-0340$\mathrm{R}$.

Tripp, R. (2000). Strategies For Seed System Development In SubSaharan Africa: a study of Kenya, Malawi, Zambia, and Zimbabwe (issue working paper series no. 2. PO Box 776, Bulawayo, Zimbabwe: Socioeconomics and policy program, international crops research Institute for the Semi-Arid Tropics). https:// doi.org/10.1139/t03-024.

Urrea-Hernandez, C., Almekinders, C. J. M., \& van Dam, Y. K. (2016). Understanding perceptions of potato seed quality among small-scale farmers in Peruvian highlands. NJAS - Wageningen Journal of Life Sciences, 76, 21-28. https://doi.org/10.1016/j.njas.2015.11.001.

von Hippel, E. (1976). The dominant role of users in the scientific instrument innovation process. Research Policy, 5(3), 212-239. https:// doi.org/10.1016/0048-7333(76)90028-7.

von Hippel, E. (1977). The dominant role of the user in semiconductor and electronic subassembly process innovation. IEEE Transactions on Engineering Management, EM-24(2), 60-71. https://doi.org/10. 1109/TEM.1977.6447336.

Wanyama, J. M., Obare, G., \& Wasilwa, L. (2016). Assessing the determinants of tissue culture Banana adoption in Western Kenya. African Journal of Food, Agriculture, Nutrition and Development, 16(1), 10742-10764. https://doi.org/10.18697/ajfand.73.14095.

Weltzien, E., Smith, M. E., Meitzner, L. S., \& Sperling, L. (2003). Technical and Institutional Issues in Participatory Plant Breeding - From the Perspective of Formal Plant (issue PPB monograph no. 1).

Witcombe, J. R., Joshi, K. D., Gyawali, S., Musa, A. M., Johansen, C., Virk, D. S., \& Sthapit, B. R. (2005). Participatory plant breeding is better described as highly client-oriented plant breeding. I. Four indicators of client-orientation in plant breeding. Experimental Agriculture, 41(3), 299-319. https://doi.org/10.1017/ S0014479705002656.

Witcombe, J. R., \& Yadavendra, J. P. (2014). How much evidence is needed before client-oriented breeding (COB) is institutionalised? Evidence from rice and maize in India. Field Crops Research, 167, 143-152. https://doi.org/10.1016/j.fcr.2014.06.022.

Zannou, A., Ahanchédé, A., Struik, P. C., Richards, P., Zoundjihékpon, J., Tossou, R., \& Vodouhè, S. (2004). Yam and cowpea diversity management by farmers in the Guinea-Sudan transition zone of Benin. NJAS - Wageningen Journal of Life Sciences, 52(3-4), 393-420.

Zannou, A., Tossou, R. C., Vodouhè, S., Richards, P., Struik, P. C., Zoundjihékpon, J., Ahanchédé, A., \& Agbo, V. (2007). Sociocultural factors influencing and maintaining yam and cowpea 
diversity in Benin. International Journal of Agricultural Sustainability, 5(2-3), 140-160. https://doi.org/10.1080/14735903. 2007.9684819.

Zawedde, B. M., Harris, C., Alajo, A., Hancock, J., \& Grumet, R. (2014). Factors influencing diversity of farmers' varieties of sweet potato in Uganda: Implications for conservation. Economic Botany, 68(3), 337-349. https://doi.org/10.1007/s12231-014-9278-3.

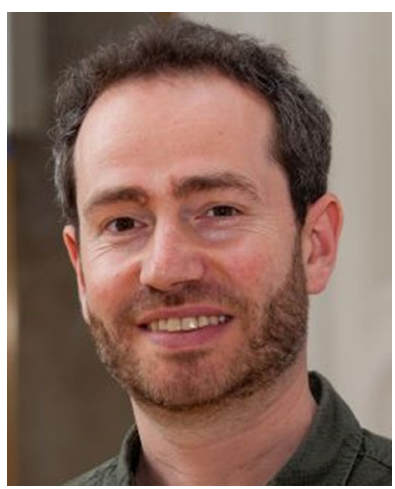

Thomas Pircher works as a program officer at the Hohenheim Research Center for Global Food Security and Ecosystems and a doctoral researcher at the Institute of Social Sciences in Agriculture at the University of Hohenheim, Germany. His research interests are understanding and facilitating innovation processes of farmers and other food system actors towards more sustainable farming and nutrition practices. Thomas manages an interdisciplinary project in Kenya and Uganda under the LEAP Agri Program and engages in research initiatives of the CGIAR Research Program on Roots, Tubers and Bananas. He holds a Master's degree in Development and Rural Innovation from Wageningen University and a Bachelor's degree in Land Management from the Technical University of Munich.

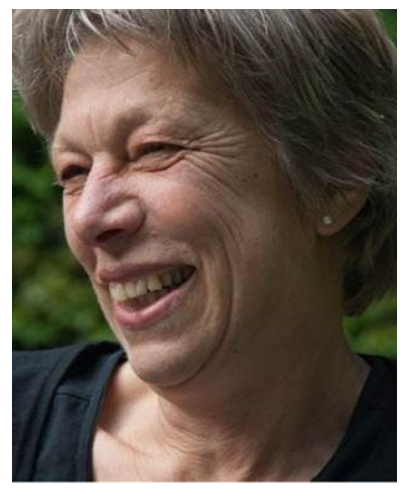

Conny Almekinders works as a social scientist in the Knowledge, Technology and Innovation (KTI) group in Wageningen University, the Netherlands. She obtained a $\mathrm{PhD}$ from the same university, based on her potato crop physiology research carried out at CIP (International Potato Centre), Peru. She worked for many years on issues related to seed systems and farmers' management of plant genetic resources, including participatory plant breeding and in situ conservation. Her shift in focus from plants to farmers, the interaction between them and with scientists has brought her into socio-technical studies of agriculture. https://www.wur.nl/en/Persons/dr.ir.-CJM-Conny-Almekinders.htm 